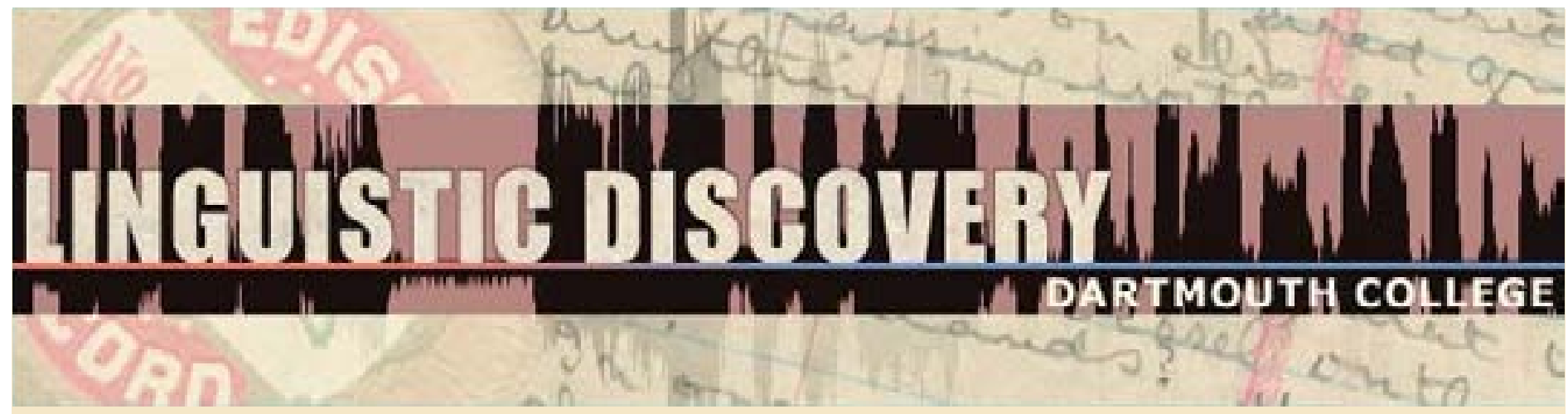

\begin{tabular}{|l|}
\hline Volume 10 \\
Issue 3 \\
2012 \\
\hline
\end{tabular}

\title{
'Give' Constructions in the Papuan Languages of Timor-Alor-Pantar
}

Marian Klamer and Antoinette Schapper

Leiden University

doi: 10.1349/PS1.1537-0852.A.421

url: http://journals.dartmouth.edu/cgi-bin/WebObjects/ Journals.woa/1/xmlpage/1/article/421

\section{Linguistic Discovery}

Published by the Dartmouth College Library Copyright to this article is held by the authors. ISSN 1537-0852 linguistic-discovery.dartmouth.edu 


\section{'Give' Constructions in the Papuan Languages of Timor-Alor-Pantar \\ Marian Klamer and Antoinette Schapper \\ Leiden University}

This paper describes three-participant 'give' constructions in ten Papuan languages of the Timor-Alor-Pantar (TAP) family. Generally lacking a class of simple ditransitive root verbs, TAP languages express 'give' events by means of biclausal constructions ('take $X$ then give $Y$ '), serial verb constructions ('take $X$ give $Y$ '), or particle-verb constructions originating in serial verb constructions. In this paper, we focus on the syntactic treatment of the gift (T), since it, unlike the other participants in 'give' constructions, displays considerable diversity across the TAP languages. Through the study of the synchronic variation in TAP 'give' constructions, we reconstruct the syntactic constructions from which the various modern constructions have developed, and sketch the grammaticalization paths that have led to them.

\section{Introduction ${ }^{1}$}

This paper presents a comparative overview of three-participant constructions containing the physical transfer verb 'give' in the Timor-Alor-Pantar (TAP) language family, and proposes a basic pattern from which these constructions developed. The TAP family consists of approximately thirty Papuan languages spread across the islands of Timor, Alor and Pantar in south-east Indonesia and East Timor. While details about the internal constituency of the family are the subject of ongoing historical work (e.g., Holton et al. forthcoming, Schapper n.d. a), it is clear that the family consists of two primary subgroups: the Alor-Pantar languages and the Timor languages. We introduce the languages further in section 2.

Generally lacking a class of ditransitive root verbs, TAP languages express three-participant events as biclausal constructions, mono-clausal serial verb constructions (SVC) or particle-verb combinations. In this paper, we focus on the expression of 'give' events, involving an agent (A), recipient $(\mathrm{R})$ and theme $(\mathrm{T})$. Through the study of the cross-linguistic variation in TAP 'give' constructions, we deduce a basic pattern from which the various constructions in the modern languages have developed, and we sketch the grammaticalization paths that have led to the modern constructions.

The TAP languages have secundative alignment (Haspelmath 2005), that is, $\mathrm{R}$ is encoded like the $\mathrm{P}$ of a mono-transitive verb, which involves co-indexing person and number of $\mathrm{R}$ with an agreement prefix on 'give'. The encoding of T, by contrast, varies across the TAP languages, as represented in (1). Mono-clausal encoding options for T include the verbs 'take' or 'come', as in $(1 \mathrm{a}, \mathrm{b})$, or a range of particles or postpositonal-like elements labelled 'OBL' in (1c). We refer to

\footnotetext{
${ }^{1}$ Acknowledgements: Many thanks go to Aone van Engelenhoven, Gary Holton, Juliette Huber, and Hein Steinhauer for their assistance in explaining aspects of their languages and providing additional examples. Our thanks also go to the two anonymous reviewers and the editor of this volume for their insightful comments. All errors are of course our own. The research for this paper was carried out as part of the ESF-EuroCORES (EuroBABEL) research project 'Alor Pantar languages: origins and theoretical impact', with financial support from the Netherlands Organisation for Scientific Research (NWO).
} 
this as flagged Ts. ${ }^{2}$ Unflagged, bare Ts also occur, in positions before or after the 'give' verb, as in (1d) and (1e).

Overview of the variation in TAP languages' coding of $\mathrm{T}^{3}$
$\begin{array}{lllllll}\text { a. } & \mathrm{A}_{\mathrm{NP}} & \mathrm{T}_{\mathrm{NP}} & \mathrm{TAKE} & \mathrm{R}_{\mathrm{NP}} & \mathrm{R}_{\mathrm{AGR}} \text {-GIVE } & \\ \text { b. } & \mathrm{A}_{\mathrm{NP}} & \mathrm{T}_{\mathrm{NP}} & \mathrm{COME} & \mathrm{R}_{\mathrm{NP}} & \mathrm{R}_{\mathrm{AGR}} \text {-GIVE } & \\ \text { c. } & \mathrm{A}_{\mathrm{NP}} & \mathrm{T}_{\mathrm{NP}} & \mathrm{OBL} & \mathrm{R}_{\mathrm{NP}} & \mathrm{R}_{\mathrm{AGR}} \text {-GIVE } & \\ \text { d. } & \mathrm{A}_{\mathrm{NP}} & \mathrm{T}_{\mathrm{NP}} & & \mathrm{R}_{\mathrm{NP}} & \mathrm{R}_{\mathrm{AGR}}-\mathrm{GIVE} & \\ \text { e. } & \mathrm{A}_{\mathrm{NP}} & & & \mathrm{R}_{\mathrm{NP}} & \mathrm{R}_{\mathrm{AGR}}-\mathrm{GIVE} & \mathrm{T}_{\mathrm{NP}}\end{array}$

In light of this considerable variation in the encoding of $\mathrm{T}$, we compare 'give' constructions across the TAP languages and consider their origins. In particular, we ask:

(i) How can we account for the variation in modern TAP 'give' constructions?

(ii) Can we reconstruct a proto-TAP 'give' construction independent of the forms used?

(iii) Are the forms in that proto-TAP 'give' construction also reconstructable?

(iv) How did the modern 'give' constructions develop from the proto-TAP construction?

We argue that the modern 'give' constructions in (1) originate in the monoclausal and biclausal proto-constructions set out in (2). The structural difference between the monoclausal and biclausal variant is the presence of a conjunction between the first and the second clause (see also section 2.1). Semantically, the constructions are also distinguished. In the monoclausal construction, the 'give' event is a serial verb construction describing a single complex event with two closely related sub-parts expressed by separate verbs. In the biclausal construction, the 'give' event consists of two separate, sequential events.

$$
\begin{array}{llll}
\text { Proto-Timor-Alor-Pantar (PTAP) 'give' constructions } & \\
\text { Monoclausal: } & \mathrm{A}_{\mathrm{NP}} \mathrm{T}_{\mathrm{NP}} \mathrm{TAKE} & \mathrm{R}_{\mathrm{NP}} & \mathrm{R}_{\mathrm{AGR}} \text {-give } \\
& \text { 'A gives T to R' } & & \\
\text { Biclausal: } & \mathrm{A}_{\mathrm{NP}} \mathrm{T}_{\mathrm{NP}} \mathrm{TAKE} \text { conjunction } & \mathrm{R}_{\mathrm{NP}} & \mathrm{R}_{\mathrm{AGR}} \text {-GIVE } \\
& \text { 'A takes T and gives to R' } & &
\end{array}
$$

We will see that in the modern TAP languags three-participant events are expressed as biclausal constructions, or as mono-clausal serial verb constructions. We also argue that in a subset of the languages, the serial verb construction grammaticalised into a complex ditransitive predicate 'give'.

This paper is structured as follows. After presenting some background to the TAP languages in section 2, we discuss the variation in synchronic 'give' constructions in Alor-Pantar languages in section 3. We consider the TAP 'give' constructions per primary subgroup: the languages

\footnotetext{
${ }^{2}$ This extends the notion of flag as used by Malchukov et. al. (2010: 8) to include light verbs as well as adpositions and case markers, as such items are often part of a continuum in the TAP languages.

${ }^{3}$ Abbreviations: AN: animate; ART: article; AGT: agent; AGR: agreement; CAUS: causative; CONJ: conjunction; CTR: contrastive; DEM: demonstrative; DIST: distal; EXCL: exclusive; FOC: focus; GEN: genitive; IPFV: imperfective; LOC: locative; NEG: negation; NMLZ: nominalizer; NSIT: new situation; OBL: oblique; PART: particle; PAT: patient; PFV: perfective; PL: plural; POSS: possessor; PNCT: punctual aspect; REAL: realis; REDUP: reduplication; REFL: reflexive; REL: relative; SEQ: sequential; SG: singular; SUBJ: subject; TAKE: light verb derived from lexical verb 'take'; TOP 'topic'.
} 
spoken on Alor and Pantar (AP) are discussed in section 3.1, while those spoken on Timor are discussed in section 3.2. In section 4, we reconstruct the 'give' constructions for Proto-TimorAlor-Pantar (PTAP) as well as the forms used in them. We present an analysis how the range of modern 'give' constructions in TAP languages arose by tracing their development from the proto-construction. Our discussion focuses on the encoding of $\mathrm{T}$, as it is the morpho-syntactic treatment of this argument which displays the most variation in TAP give constructions. In particular, we highlight morpho-syntactic details of 'give' constructions in individual languages which indicate the reanalysis of the morpheme that flags the $\mathrm{T}$ constituent (section 4.1), the development of particle-verb 'give' constructions (section 4.2), the fusion of the verb 'take' with the verb 'give' (section 4.3), and the development of bare T constructions (section 4.4). Section 5 contains a summary and conclusions.

\section{Background to the Timor-Alor-Pantar Languages}

The ten TAP languages we will look at in this paper are: Western Pantar and Teiwa from Pantar (Holton and Lamma Koly 2008, Holton pers. comm. 2011, Klamer 2010a, b, c, n.d.); Blagar from the Pantar Straits (Steinhauer pers. comm. 2010, 2011); Klon, Abui and Kamang from Alor (Baird 2008, n.d., Kratochvíl 2007, Schapper n.d. b); and Bunaq, Makasae, Makalero and Fataluku from Timor island (Schapper 2010, Huber 2005, 2011, pers. comm. 2011, Van Engelenhoven 2006, pers. comm. 2011).

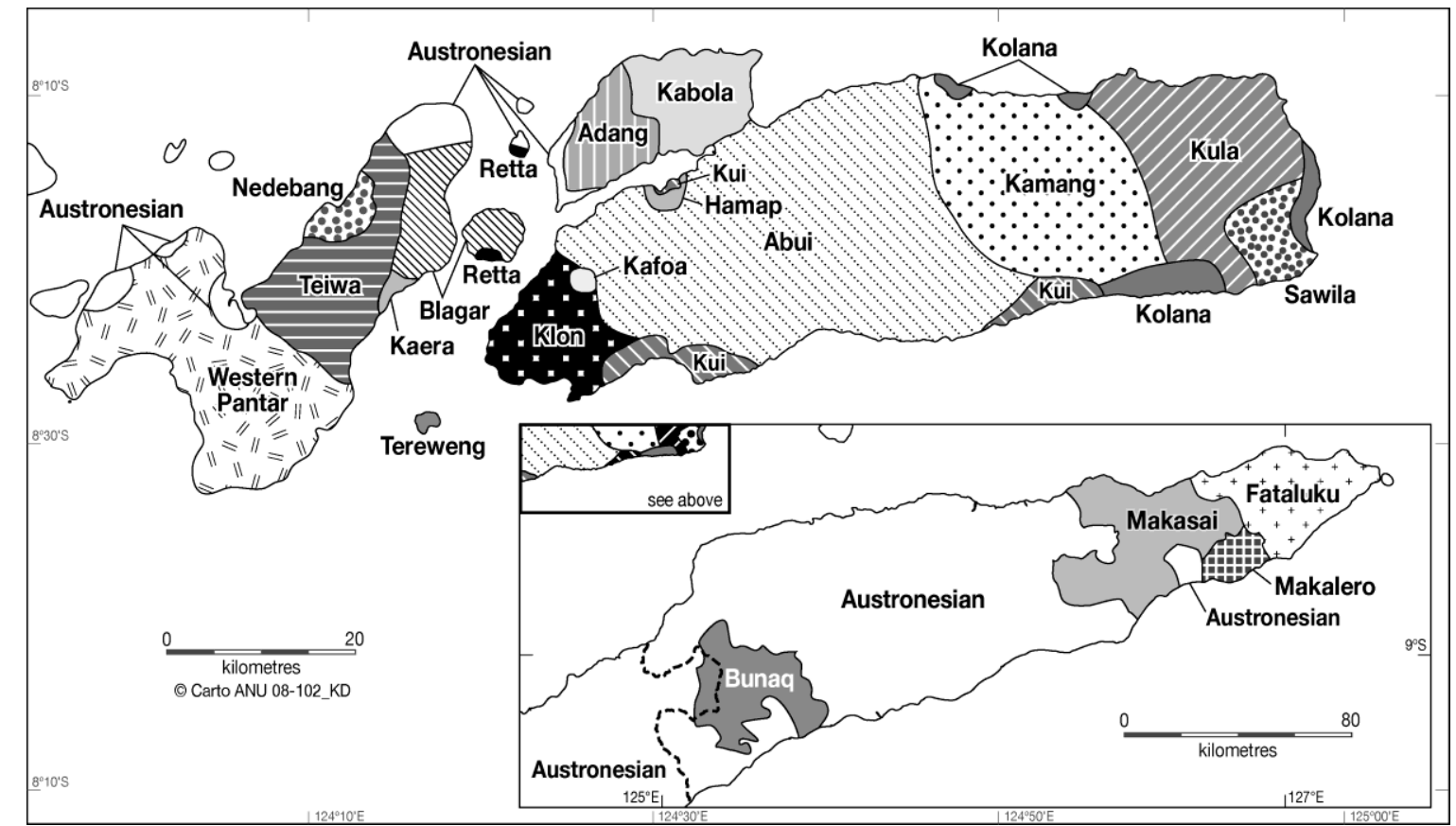

Map 1: Papuan languages of the Timor-Alor-Pantar family (from Schapper 2010:21). (Adjacent languages belonging to the Austronesian family are not referred to individually on the map.)

\subsection{Serial verbs and bi-clausal constructions in TAP}

Except for Bunaq, clauses in TAP languages are verb-final; Ps precede the verb. We argue that the TAP languages express three-participant events as biclausal constructions or serial verb constructions (SVCs) and define these notions here. SVCs are defined as two or more verbs that 
occur together in a single clause, which share minimally one argument, and whose shared argument(s) is (are) expressed maximally once. SVCs are thus analysed as mono-clausal constructions, which are distinguished from bi-clausal constructions by the presence of a clause boundary marker in between the clauses in the latter. The boundary marker could be a conjunction-like element encoding simultaneous (SIM) or sequential (SEQ) events, and/or a break in the intonation contour. The verbs in a SVC share tense and aspect marking and occur under a single intonation contour without a break or a pause.

The semantic contrast between a mono-clausal construction with an SVC and a biclausal construction is illustrated by the minimally contrasting pair of Teiwa sentences in (3). Monoclausal (3a) describes the intransitive event of someone who died because he fell down (e.g. from a coconut tree) by using a SVC. The biclausal construction in (3b) describes two events in clauses that are linked by the sequential conjunction ba: someone is dying (e.g., because of a heart attack) and is falling down (e.g., out of a tree) as a result of this. No such conjunction-like element could occur between the verbs of a SVC.

Teiwa
a. A ta min-an ba?.
3s TOP die- REAL fall.down
'He died falling down'
b. A ta min-an ba ba?.
3s TOP die-REAL SEQ fall.down
'He died then fell down'

In the sections below we will consider SVCs consisting of the two transitive verbs 'take' and 'give'. It will be seen that in such SVCs, the non-final (medial) verb can grammaticalize into a light verb, particle or postpositonal-like element which we label 'OBL' here.

\subsection{Monotransitive alignment in TAP}

Before turning to ditransitive clauses, we will outline the morphological alignment patterns displayed by TAP languages in monotransitive clauses. Monotransitive alignment in TAP languages vary in respect to two main characteristics: (i) number of prefixal inflections (zero to six), and; (ii) alignment type (split-S, accusative, no morphological marking of arguments). ${ }^{4}$ Split-S alignment is defined here as the alignment where the single argument of an intransitive verb (S) is sometimes coded like the agentive argument of a transitive verb (A) and other times like the patientive argument of a transitive verb $(\mathrm{P})$. Accusative alignment is where $\mathrm{S}$ and $\mathrm{A}$ are treated alike as opposed to $\mathrm{P}$.

Table 1 presents an overview of these broad patterns in the TAP languages discussed in this paper. ${ }^{5}$ It is beyond the scope of this paper to deal with the details of all the different languages.

\footnotetext{
${ }^{4}$ This section presents a brief overview of alignment patters in TAP languages. For additional details and discussion we refer to the descriptions of the individual languages (see the references cited in section 2), Fedden et.al. to appear, and Klamer 2008.

${ }^{5}$ These are by no means the only types found in the languages. For instance, Adang has three prefixes series, like Klon, but aligns them accusatively (Haan 2001). Languages of eastern Alor such as Sawila have aligned prefixes on a direct-inverse pattern (Kratochvíl et. al. 2011).
} 


\begin{tabular}{llll}
\hline Island & Language name & $\begin{array}{l}\text { No. of prefix } \\
\text { paradigms }\end{array}$ & Alignment \\
\hline Pantar & Western Pantar & 1 & split-S \\
& Teiwa & 1 & accusative \\
Pantar Straits & Blagar & 1 & accusative \\
Alor & Klon & 3 & split-S \\
& Abui & 5 & split-S \\
\multirow{3}{*}{ Timor } & Kamang & 6 & split-S \\
& Bunaq & 1 & accusative \\
& Makalero & $(1)$ & (accusative) \\
& Makasae & -- & -- \\
& Fataluku & -- & -- \\
\hline
\end{tabular}

The TAP languages on Pantar and Pantar Straits have only a single paradigm of prefixes. The paradigms of the three languages discussed in this paper are given in Table 2.

\begin{tabular}{|c|c|c|c|c|c|}
\hline & Western P. & & Teiwa & & Blagar \\
\hline $1 \mathrm{SG}$ & na- & $1 \mathrm{SG}$ & $n(a)-$ & $1 \mathrm{SG}$ & $n-$ \\
\hline $2 \mathrm{SG}$ & ha- & $2 \mathrm{SG}$ & $h(a)-$ & $2 \mathrm{SG}$ & $\varnothing$ \\
\hline $3 \mathrm{SG}$ & $g a-/ a-$ & $3 \mathrm{SG}$ & $g(a)-$ & $3 \mathrm{SG}$ & P- \\
\hline 1PL.EX & $n i-$ & 1PL.EX & $n(i)-$ & 1PL.EX & $n i-$ \\
\hline 1PL.IN & $p i-$ & 1PL.IN & $p(i)$ & 1PL.IN & $p i-$ \\
\hline $2 \mathrm{PL}$ & $h i-$ & $2 \mathrm{PL}$ & $y(i)-$ & $2 \mathrm{PL}$ & $i-$ \\
\hline 3PL & $g i-$ & $3 \mathrm{PL}$ & $g(i)-\sim g a-$ & 3PL & $2 i-$ \\
\hline
\end{tabular}

Of these languages, only Western Pantar has a split-S system. We see in the examples below that a prefix can index a P (4a) and an S (4b). Some verbs, such as diti 'stab' in (4c) and (4d), even allow an alternation in the coding of a $\mathrm{P}$ or $\mathrm{S}$ with either a prefix or a free pronoun, with a difference in the degree of affectedness resulting. By contrast, Teiwa and Blagar prefixes exclusively index the $\mathrm{P}$ of a monotransitive clause and not the $\mathrm{S}$ of an intransitive clause (5). Note, however, that not all Ps are indexed by a prefix in Teiwa: while almost all Ps which are indexed are animate, many inanimate Ps are not indexed (Fedden et.al. forthcoming).

Western Pantar (Holton 2010)

A P-V

a.

'Markus 1sG-see

S-V

b. Na-pia.

1SG-descend

'I went down' 

A
P-V
c. Markus
na-diti.
Markus
1SG-stab
$\begin{array}{llll} & \text { A } & \text { P } & \text { V } \\ \text { d. } & \text { Markus } & \text { naing } & \text { diti. } \\ & \text { Markus } & \text { 1SG } & \text { stab }\end{array}$
'Markus stabbed me (superficially).'
'Markus stabbed me (severely).'

Teiwa

(5)

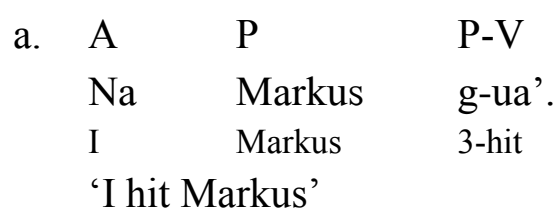
b. $\mathrm{S} \quad \mathrm{V}$
A min-an tau.
s/he die-REAL PRF
'He died already.'

The languages of Alor discussed in this paper all have complex systems of split-S alignment involving multiple paradigms of inflectional prefixes. Klon has three inflections (Table 3), Abui five (Table 4) and Kamang six (Table 5).

\begin{tabular}{llll}
\hline & I & II & III \\
\hline 1SG & $n-$ & $n e-$ & $n o-$ \\
2SG & $V-/ \varnothing-$ & $e-$ & $o-$ \\
3 & $g-$ & $g e-$ & $g o-$ \\
1PL.EX & $n g-$ & $n g e-$ & $n g o-$ \\
1PL.IN & $t-$ & $t e-$ & to- \\
2PL & $i-$ & ege- & ogo- \\
\hline \multicolumn{4}{l}{ Table 3: Klon person prefixes }
\end{tabular}

\begin{tabular}{llllll}
\hline & I & II & III & IV & V \\
\hline 1SG & $n a-$ & $n e-$ & $n o-$ & $n e e-$ & $n o o-$ \\
2SG & $a-$ & $e-$ & $o-$ & $e e-$ & $o o-$ \\
3 & $h a-$ & $h e-$ & $h o-$ & $h e e-$ & $h o o-$ \\
1PL.EX & $n i-$ & $n i-$ & $n u-$ & $n i i^{-}$ & $n u u-$ \\
1PL.IN & $p i-$ & $p i-$ & $p u-$ & $p i i-$ & $p u u-$ \\
2PL & $r i-$ & $r i-$ & $r u-$ & $r i i-$ & $r u{ }^{-}$ \\
\hline \multicolumn{5}{c}{ Table 4: Abui person prefixes }
\end{tabular}




\begin{tabular}{|c|c|c|c|c|c|c|}
\hline & I & II & III & IV & $\mathrm{V}$ & VI \\
\hline $1 \mathrm{SG}$ & na- & $n e-$ & no- & nee- & noo- & nao- \\
\hline $2 \mathrm{SG}$ & $a-$ & $e-$ & $O-$ & $e e-$ & $O O-$ & $a o-$ \\
\hline 3 & ga- & $g e-$ & $W O-$ & gee- & WOO- & gao- \\
\hline 1PL.EX & $n i-$ & $n i-$ & nio- & nii- & nioo- & nioo- \\
\hline 1PL.IN & $S i-$ & Si- & Sio- & Sii- & SiOO- & SiOo- \\
\hline $2 \mathrm{PL}$ & $i-$ & $i-$ & io- & $i i-$ & ioo- & ioo- \\
\hline
\end{tabular}

Each of these prefixal inflections can index either $\mathrm{S}$ or $\mathrm{P}$, but the choice of inflection is highly dependent on the lexical identity of the verb at issue. For instance, in Klon (Baird 2005, 2008) the transitive verb - krui 'scream' indexes its $\mathrm{P}$ with a class III prefix (6a), while the intransitive verb -hrak 'hot' indexes its $\mathrm{S}$ with a class III prefix (6b). Neither verb can take a I or II class prefix. Also, the absence of a prefix indexing an argument cannot be said to indicate that a participant is agentive, since we find both transitive verbs whose $\mathrm{P}$ is not indexed by a prefix (6c) and intransitive verbs whose $S$ is not indexed by a prefix (6d).

Klon (Baird 2008)

(6)

\section{A $\quad \mathrm{P} \quad \mathrm{P}-\mathrm{V}$}

a. $\mathrm{Na}$

$1 \mathrm{SG}$

Markus go-ihih.

Markus 3.III-wake

'I wake Markus.'
S

b. Markus

Markus

'Markus is tired.'

\section{$\mathrm{S}$}

d. Markus

Markus

'Markus is itchy.'
S-V

go-egel.

3.III-tired

V

kaak. itchy

'I hit Markus.'

Abui and Kamang show a greater amount of flexibility in their use of prefixes, but nevertheless, here too lexical classes play an important role in determining prefixation patterns of $\mathrm{S}$ in intransitive clauses and $\mathrm{P}$ in transitive clauses. There is no flexibility in the choice of prefix on verb roots requiring a prefix to index either $\mathrm{S}$ or $\mathrm{P}$; that is, verb roots with obligatorily prefixation are distributed into lexicalised inflectional classes. For instance, in Abui (7) and Kamang (8), examples (a) show an intransitive verb encoding S with a prefix, and examples (b) present a transitive verb which encodes $P$ with a prefix like the verb in (a). In each case here, the inflection I prefix cannot be left off the verb or replaced by a prefix of another inflection. That is, the relation between verb root and prefix is fixed.

Abui (Schapper fieldnotes)

(7)

S-marking inflection I
a. Na-kaai.
1SG.I-collapse
'I collapsed.'

\section{P-marking inflection I}

b. Markus na-mul.

Markus 1SG.I-wound

'Markus wounded me.' 
Kamang (Schapper fieldnotes)

$$
\text { S-marking inflection I }
$$

a. Na-maitan-si.

1SG.I-hunger-IPFV

'I'm hungry.'
P-marking inflection I

b. Markus na-tak-si.

Markus 1SG.I-see-IPFV

'Markus sees me.'

In Abui, however, many verb roots allow the alternation of prefixes. For instance, the Abui verb root -hayei can occur with multiple different prefixes with slightly different meanings: (i) a prefix of inflection I encoding S to mean 'fall' (9a); (ii) a prefix of inflection III encoding S to mean 'almost fall' (9b), and; (iii) a prefix of inflection $\mathrm{V}$ encoding $\mathrm{P}$ to denote a transitive event whereby one entity falls on another (9c). By contrast, Kamang prefixes are basically only interchangeable on verbs which have no obligatory prefix. For instance, the intransitive verb silanta can appear by itself (10a) or with different prefixes encoding different semantic kinds of P participants (10b-d).

Abui (Schapper fieldnotes)

S-marking inflection I

a. Na-hayei.

1SG.I-fall

'I fall.'

P-marking inflection $\mathrm{V}$
P-marking inflection III

b. No-hayei.

1SG.III-fall

'I almost fall.'

Kamang (Schapper fieldnotes)

(10)
a. Markus silanta.
Markus wail
'Markus wails.'
P-marking prefix inflection IV
c. Markus nee-silanta.
Markus 1SG.IV-wail
'Markus wails for me.'

\section{P-marking inflection III}
b. Markus no-silanta.
Markus 1SG.III-wail
'Markus wails over me.'
P-marking prefix inflection $\mathrm{V}$
d. Markus noo-silanta.
Markus 1SG.V-wail
'Markus wails with my assistance.'

On Timor, prefixes are much eroded, but are consistently aligned accusative where they remain. Bunaq has completely lost a number distinction in its prefixes due to the thoroughgoing effects of vowel harmony. The remaining prefixes are marked for person only (11a). The third person prefix $g V$ - has specialised to only be used with Ps which refer to a noun with animate gender 
only (Schapper 2010: 172-186). As a result, there is differential marking of P, with animates Ps getting a prefix (11b) and inanimate Ps no prefix (11c). ${ }^{6}$

$$
\begin{aligned}
& \text { Bunaq prefixation } \\
& \text { a. 1EX } n V- \\
& 1 \mathrm{IN} / 2 \quad V- \\
& 3 \mathrm{AN} \quad g V-
\end{aligned}
$$

b. Neto zap gi-wit.

$1 \mathrm{SG} \quad \operatorname{dog}$ 3AN-fetch

'I fetched the dog.'

c. Neto zo wit.
1sG mango fetch
'I fetched the mango.'

Whilst Bunaq retains roughly half of the prefixes of Pantar languages, these have been all but lost in the other Papuan languages of Timor. Only in Makalero do we find agreement morphology preserved in a small set of verbs inflecting with $k$-for a $\mathrm{P}$ argument (examples given in (12), cf. Huber 2008)). This prefix is a cognate of Bunaq $g V$ - ' $3 \mathrm{AN}$ ' and reflects a reduction of PTAP $3{ }^{\text {rd }}$ person prefixes $* g a$ - ' $3 \mathrm{SG}^{\prime}$ ' and $* g i$ - ' $3 \mathrm{PL}$ '. In Makasae, cognates of Makalero inflecting verbs variably reflect the uninflected root and the root with the fossilised prefix $*_{\mathrm{g}}$-, cognate to Makalero $k$-. In Fataluku, the cognate items are invariably found without a prefix.

(12) Examples of Makalero inflecting verbs and their cognates in East Timor languages

(Schapper et al. forthcoming).

$\begin{array}{lllll}\text { Inflected } & \text { Uninflected } & & \text { Makasae } & \text { Fataluku cognate } \\ \text { k-form } & \text { vowel-form } & & \text { cognate } \\ \text { kuta } & \text { uta } & \text { 'kill' } & \text { guta } & \text { uta 'hit' } \\ \text { kene } & \text { ene } & \text { 'hit' } & \text { gene } & -- \\ \text { kutu } & \text { utu } & \text { 'block' } & \text { gutu } & \text { utu } \\ \text { kata } & \text { ata } & \text { 'contact' } & \text { gata } & \text { aca } \\ \text { kumu } & \text { umu } & \text { 'die' } & \text { umu } & \text { umu } \\ \text { kafu } & \text { afu } & \text { 'carry' } & \text { gapu \& apu' } & \text { apu'with' }\end{array}$

In short, the languages of the TAP family show great variation in the morphological realisation and syntactic alignment of monotransitive clauses. The diversity in the coding of $\mathrm{P}$ seen here will contrast in the following sections with the great consistency in the treatment of ditransitive $\mathrm{R}$ as

\footnotetext{
${ }^{6}$ The situation in Bunaq is actually slightly more complex with some classes of verbs that have a distinct prefix for inanimate Ps rather than no prefix. See Schapper 2010: 337-350.

${ }^{7}$ In this case, both the uninflected and inflected verb form are retained in Makasae with lexicalised meanings: the uninflected form apu is a transitive verb 'carry' and the inflected form gapu is a postposition 'with'.
} 
the prefixed argument of the 'give' verb across the same languages. Instead we will see that it is the ditransitive $\mathrm{T}$ which has all the variation in its treatment from language to language.

\section{3. 'Give' Constructions in Timor-Alor-Pantar}

This section presents an overview of the 'give' constructions in ten Timor-Alor-Pantar languages, according to their subgroup. Six Alor-Pantar languages are discussed in section 3.1, four Timor languages are discussed in section 3.2. Our data comes from the sources mentioned in section 2.1 .

\section{1 'Give' in Alor-Pantar languages}

In the following sections, we discuss the encoding of 'give' events in six Alor-Pantar languages. Most of the AP languages use cognates of Proto-Timor-Alor-Pantar (PTAP) *med 'take' and *-en(a/i) 'give' in their 'give' construction. In several AP languages the verb 'come' (reflecting Proto-Alor-Pantar (PAP) *ma 'come') is also involved in the 'give' construction. Table 6 presents an overview of the forms.

\begin{tabular}{|c|c|c|c|}
\hline & $\begin{array}{l}\text { ‘TAKE' } \\
<\text { PTAP *med }\end{array}$ & $\begin{array}{l}\text { 'GIVE' } \\
<\text { PTAP *-en }(\mathrm{a} / \mathrm{i})\end{array}$ & $\begin{array}{l}\text { 'COME' } \\
<\text { PAP *ma }\end{array}$ \\
\hline Klon & med & -en & $m a$ \\
\hline WPantar & $\{$ haggi $\} \dagger$ & $-n i a$ & $m a$ \\
\hline Abui & $m i$ & $\{-1 \sim-r\}$ & -- \\
\hline Kamang & me & $-n$ & -- \\
\hline Blagar & met- & -enang & $m a$ \\
\hline Teiwa & -- & $-a n$ & $m a$ \\
\hline
\end{tabular}

In our survey we focus on the flagging of $\mathrm{T}$ in Alor-Pantar languages. This is because there is great variation in T-flagging to be observed across the languages. As we shall see in the coming sections, four broad strategies are attested: (i) $\mathrm{T}$ flagging with a verb 'take' (see 1a); (ii) $\mathrm{T}$ flagging with a verb 'come' (see 1b); (iii) $\mathrm{T}$ flagging with an oblique particle which grammaticalised from 'take' or a collocation of 'take' and 'come' (see 1c), and; (iv) no flagging of $\mathrm{T}$ (see (1d-e)). In examining the different T-flagging strategies in the individual languages, we pay particular attention to the synchronic status of the item(s), if any, that are flagging $\mathrm{T}$. Later, in the reconstruction proposed in section 4 we use these details to argue for particular grammaticalisation pathways of the 'give' verb in Alor-Pantar languages.

KLON

Klon allows a biclausal 'give' construction. The two verbs necessarily involved are 'take' and 'give'. In a biclausal construction, $\mathrm{T}$ is flagged in the first clause by med 'take' and $\mathrm{R}$ in the second clause by -en 'give'. The two clauses are conjoined by $d e$ 'CONJ', which syntactically separates the 'take' event from the 'give' event. For instance: 


$\begin{array}{llllll} & \text { T } & & \text { TAKE } & \text { CONJ } & \text { R-GIVE } \\ \ldots \text {...ege } & \text { bah } & \text { op } & \text { med } & \text { de } & \text { g-en. } \\ \text { 2PL } & \text { needle } & \text { DEM } & \text { take } & \text { CONJ } & \text { 3-give }\end{array}$

'...you took that needle to give to him.'

$\begin{array}{llllll} & \text { T } & & \text { TAKE } & \text { CONJ } & \text { R-GIVE } \\ \text { Mede } & \text { bah } & \text { ong } & \text { med } & \text { de } & \text { n-en. } \\ \text { climb needle } & \text { DEM } & \text { take } & \text { CONJ } & \text { 1sG-give } \\ \text { 'Climb [up] get this needle for me.' (Baird n.d.) }\end{array}$

A second construction is a serial verb construction where $m a$ 'come' can occur in between med 'take' and -en 'give'. This is illustrated in (15). In such cases, $m a$ is a serial verb which signals the transposition from the 'take' event to the 'give' event, functionally much like de 'CONJ' does in (13) to (14).

\begin{tabular}{|c|c|c|c|c|c|c|c|}
\hline & & & $\mathrm{T}$ & TAKE & COME & $\mathrm{R}$ & R-GIVE \\
\hline $\begin{array}{l}\text { Ul } \\
\text { child }\end{array}$ & $\begin{array}{l}\text { yo } \\
\text { DEM }\end{array}$ & $\begin{array}{l}\text { ga } \\
3 \mathrm{SG}\end{array}$ & $\begin{array}{l}\text { doi } \\
\text { money }\end{array}$ & $\begin{array}{l}\text { med } \\
\text { take }\end{array}$ & $\begin{array}{l}\text { ma } \\
\text { come }\end{array}$ & $\begin{array}{l}\text { n-iman } \\
\text { 1SG-father }\end{array}$ & $\begin{array}{l}\text { g-en. } \\
\text { 3-give }\end{array}$ \\
\hline
\end{tabular}

The resulting sequence of $m e d$ and $m a$ can be reduced to simply $m a$, as in (16a). We analyse this as a grammaticalised construction where the verb med has been omitted, as indicated by the empty element in (16b): the nominals ege '2PL' and $a k$ 'half' were originally the A and $\mathrm{P}$ of 'take', which shared its A argument with 'give'. The omission of 'take' lead to a synchronic 'give' construction where $\mathrm{T}$ is flagged by $m a$ 'come', as in (16a).

$$
\begin{aligned}
& \text { A } \mathrm{T} \text { COME } \mathrm{R} \text { R-give } \\
& \begin{array}{lllllll}
\text { a. } & \text {...bo } & \text { ege } & \text { ak } & \text { ma } & \text { kur } & \text { g-en, } . . . \\
\text { so } & 2 \mathrm{PL} & \text { half } & \text { come } & \text { dog } & \text { 3-give }
\end{array} \\
& \text { '...so you give half to the dog, ...' } \\
& \mathrm{T} \text { TAKE COME } \mathrm{R} \text { R-gIVE }
\end{aligned}
$$

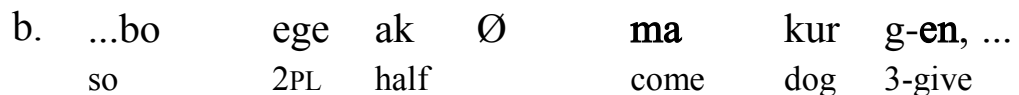

$$
\begin{aligned}
& \text { '...so you give half to the } \mathrm{dog}, . . .
\end{aligned}
$$

Finally, Klon also allows T to occur without any flagging. That is, two NPs can occur before the verb -en 'give': T encoded by a simple NP without flagging of any kind followed by R encoded by a prefix on -en and optionally co-indexed by a NP. Illustrations are given in (17) and (18). Examination of corpus data for Klon reveals that 'give' with bare $\mathrm{T}$ is less frequent than both the serialised and biclausal constructions. 


$\begin{array}{lllll} & & \text { T } & \text { R } & \text { R-GIVE } \\ \text { Gan } & \text { ga } & \text { doi } & \text { ni-man } & \text { g-en. } \\ \text { 3SG } & \text { 3SG } & \text { money } & \text { 1sG-father } & \text { 3-give }\end{array}$

'S/he gave money to my father'

$\begin{array}{lllll}\text { (18) Ini ngan } & \text { hok } & \text { eg-en=e } & \text { nang? } \\ 3 \mathrm{PL} & \text { thing } & \text { some } & \text { 2PL-give=PART } & \text { NEG }\end{array}$

'Did they give you things or not?' (Baird 2008: 126)

In short, Klon has four possible ways of coding T: (i) T flagged with med 'take' in its own clause conjoined to the clause with -en 'give' by de 'CONJ'; (ii) T flagged with med followed by ma 'come' in the same clause as -en; (iii) T flagged with by $m a$ in the same clause as -en, and; (iv) T unflagged.

\section{WESTERN PANTAR}

Like Klon, Western Pantar has several codings for 'give' (Holton and Lamma Koly 2008: 111). The first is a serial verb construction in which $\mathrm{T}$ is flagged by haggi 'take' and $\mathrm{R}$ by -nia 'give', as in (19). Where T is implicit, haggi can either occur without it, as in the first clause of (20), or haggi can be omitted entirely, represented as the empty element in the second clause of (20).

$\begin{array}{lll}\text { T } & \text { TAKE } & \text { R-GIVE } \\ \text { Na-iti } & \text { haggi } & \text { na-nia. } \\ \text { 1SG-glasses } & \text { take } & \text { 1sG-give }\end{array}$

'Give me my eyeglasses.' (eyeglasses are right at hand, perhaps on the table)

$\begin{array}{lllllll}\text { TAKE } & \mathrm{R} & \text { R-GIVE } & & \text { TAKE } & \text { R } & \text { R-GIVE } \\ \text { Haggi } & \text { naing } & \text { na-nia, } & \text { palliba } & \varnothing & \text { tuang } & \text { ga-nia? } \\ \text { take } & \text { 1SG.PAT } & \text { 1sG-give } & \text { why } & & \text { official } & \text { 3sG-give }\end{array}$

'[The harvest] gave me [this], why [should I] give [it] to the official?'

In a second 'give' construction, the verb (a)ma 'come' (the optional /a/ is a prothetic vowel) occurs between haggi and -nai, as in (21). The use of $m a$ implies a movement of the person taking the pen, as shown by the semantic contrast between (19) above, where $\mathrm{T}$ is right at hand, and (21) below, where $\mathrm{T}$ is brought from another location. In other words, Western Pantar (a)ma functions much like Klon $m a$ in (13), signalling the movement from the 'take' event to the 'give' event.

$\begin{array}{lllll}\text { T } & & \text { TAKE } & \text { COME } & \text { R-GIVE } \\ \text { Potol } & \text { saina } & \text { haggi } & \text { ama } & \text { na-nia. } \\ \text { pen } & \text { DEM } & \text { take } & \text { come } & \text { 1SG-give }\end{array}$

'Take that pen and give it to me.' (pen brought from a distance) 
Western Pantar reduces the sequence of haggi 'take' and (a)ma 'come' such that on the surface (a)ma flags $\mathrm{T}$, as in (22) and (23). The use of (a)ma and -nia without haggi is common, but perceived by speakers as informal speech.

$\begin{array}{lllll} & \text { T } & \text { TAKE } & \text { COME } & \text { R-GIVE } \\ \text { Nang } & \text { maggi } & \varnothing & \text { ma } & \text { ga-nia. } \\ \text { 1SG } & \text { banana } & & \text { come } & \text { 3sG-give }\end{array}$

'I give a banana to him'

$$
\text { T COME R-GIVE }
$$

$\begin{array}{llll}\text { Luppa } & \text { ama } & \text { na-nia } & \text { ta. } \\ \text { a.little } & \text { come } & \text { 1sG-give } & \text { first }\end{array}$

'Give me a little.' (addressee is holding a mango)

Finally, West Pantar has a less frequent 'give' construction in which T receives no flagging, as in (24).

$$
\begin{aligned}
& \mathrm{T} \\
& \text { Bes hatianing na?ai ha-nia. } \\
& \text { mango ripe } \\
& \text { 'I am giving you a ripe mango.' }
\end{aligned}
$$

In sum, Western Pantar has variable 'give' constructions like those found in Klon; but its lexeme for 'take' is not cognate with PTAP *med, and, unlike Klon, Western Pantar has no biclausal variant of the 'give' construction.

ABUI

Like Klon, Abui has a biclausal 'give' construction in which $\mathrm{T}$ is flagged in the first clause by $m i$ 'take' and $\mathrm{R}$ in the second clause by $-l \sim-r$ 'give' (the consonant alternation encodes an aspectual distinction which need not concern us here). The two clauses are conjoined by $b a$ 'CONJ', as in (25) and (26).

$\begin{array}{llllll}\text { T } & \text { TAKE } & & \text { R } & & \text { R-GIVE } \\ \text { Hen } & \text { mi } & \text { ba } & \text { Lius } & \text { la } & \text { he-1-e. } \\ 3 & \text { take } & \text { CONJ } & \text { Luis } & \text { PART } & \text { 3-give-IPFV } \\ \text { 'Just give that one to Lius.' }\end{array}$

..,$\quad$ hare $\operatorname{mi} \quad$ ba
so take he-l-e.
'..., so give (it) to him.'

More commonly, however, Abui makes use of a monoclausal 'give' construction where $m i$ 'take' flags T. This is illustrated by the examples in (27) and (28). Note the fronting of the NP encoding 
$\mathrm{R}$ in (27) to a position before both 'give' and 'take' verbs. This would not be possible in the biclausal structure where there is a clausal boundary between verbs.

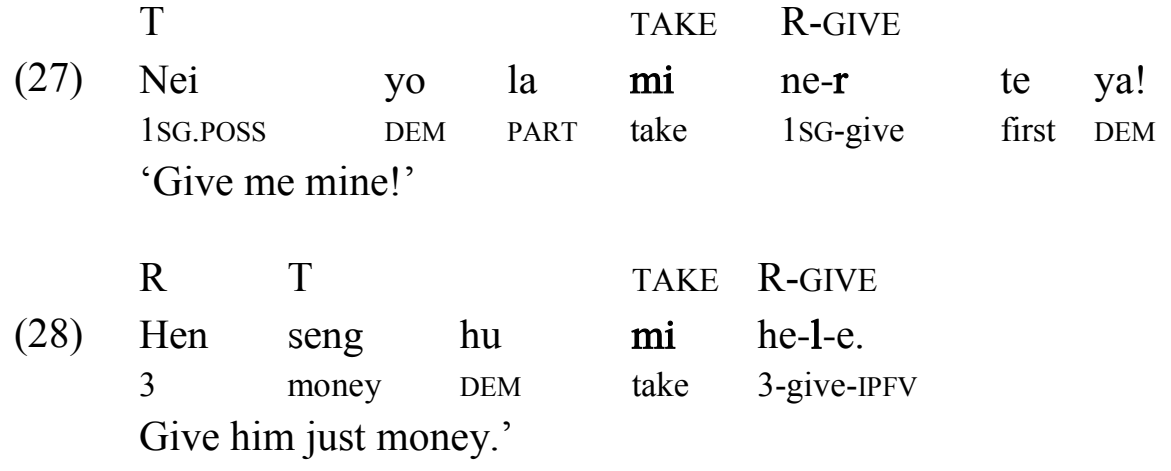

Finally, Abui also has a less frequent 'give' construction in which $m i$ 'take' does not appear. Of some fifty examples identified in the corpus, the ones in (29) and (30) are the only ones without $m i$. This construction only occurs in hortative or imperative speech acts, where $\mathrm{T}$ is clause initial, indicating its use is conditioned by a particular speech situation.

\begin{tabular}{llll} 
T & \multicolumn{3}{c}{ R-GIVE } \\
Nei & nuku & e-1! \\
1SG.POSS & one & 2SG-give \\
'[I will] give you mine!' & \\
T & & R-GIVE \\
Mayol & nu & la & ne-1-o! \\
1SG.POSS & ART & PART & 1SG-give-PNCT
\end{tabular}

'Give me a woman!'

In a nutshell, Abui can code $\mathrm{T}$ in the following ways: (i) $\mathrm{T}$ flagged with $m i$ 'take' in its own clause conjoined to the clause with $-r \sim-l$ 'give' by $b a$ 'CONJ'; (ii) T flagged with $m i$ in the same clause as $-r \sim-l$; (iii) T unflagged.

KAMANG

Kamang has only one mono-clausal 'give' construction. In this construction, $\mathrm{R}$ is the encoded by a genitive prefix on the verb $-n$ 'give' and an optional independent co-referent NP; $T$ is flagged by me. For instance:
TAKE $\mathrm{R}$
R-give
a. Maria seng me ge-paa ge-n.
Maria money TAKE 3.GEN-father 3.GEN-give
$\mathrm{T}$
'Maria gave money to her father.' 

$\begin{array}{lllll} & & \text { T } & \text { TAKE } & \text { R-give } \\ \text { b. Marten } & \text { kui } & \text { me } & \text { ni-n-ma. } \\ \text { Marten } & \text { dog } & \text { TAKE } & \text { 1PL.EXCL.GEN-give-PFV }\end{array}$
'Marten gave a dog to us.'

Kamang $m e$ is in fact not a full lexical verb but a reduction of the verb met 'take' which is used to introduce NPs with peripheral thematic roles, such as instruments, into a clause. Me is a light verb that does not typically occur as a clause-final independent verb, and, on the rare occasions that it does, it cannot host aspectual suffixes in the manner of a full lexical verb. Compare:
a. Marten
ne-kine
n-at
1SG-FROM
me.
(*me-si,
*me-ma)
Marten
1SG.GEN-knife
me.'
b. Marten
n-at
1SG.GEN-knife 1SG-FROM
ne-kine
met. (met-si,
met-ma)
Marten
take take-IPFV take-PFV

'Marten took my knife from me.'

Whilst Kamang $-n$ 'give' can host aspectual inflection, it cannot be considered a fully independent verb either, since a clause with $-n$ must always also contain me. For instance, even where the $\mathrm{T}$ is elided, me must appear in the clause with $-n$, as in (33a). The dropping of me results in a speaker judging the clause to be ungrammatical (33b). Similarly, in benefactive serialisation with $-n$, me must be included, although its $\mathrm{P}$ is always co-referent with the $\mathrm{P}$ of the preceding bivalent verb (34).
a. Maria me ne-n.
Maria TAKE 1SG.GEN-give
'Maria gives (it) to me.'
b. ${ }^{*}$ Maria ne-n.
Maria 1SG.GEN-give
(34) Maria falak sine me ne-n.
Maria cloth weave TAKE
'Maria weaves a cloth for me.'

In sum, in Kamang 'give' constructions, the two verbs 'take' and 'give' must occur together, and the verb 'take' used in these constructions is phonologically and syntactically reduced.

BLAGAR

Blagar has two monoclausal 'give' constructions. In the first, a 'give' event is constructed with the lexeme metma 'OBL', which flags T, as in (35). 


$\begin{array}{llllll}\mathrm{Na} & \text { vet } & \mathrm{nu} & \text { metma } & \text { n-oPal } & \text { 1-enang. } \\ \text { 1SG } & \text { coconut } & \text { one } & \text { OBL } & \text { 1SG-child } & \text { 3SG-give }\end{array}$

'I give a coconut to my child'

Metma is an obligatory part of the construction: it cannot be omitted, even when the referent of $\mathrm{T}$ is implied, as shown by the grammaticality contrast in (36a) and (36b).

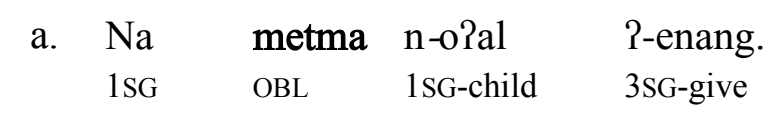

'I give (it) to my child.'

$$
\begin{array}{llll}
\text { b. } & \mathrm{Na} & \text { n-oPal } & \text { 2-enang. } \\
& \text { 1SG } & \text { 1sG-child } & \text { 3sG-give }
\end{array}
$$

Metma is used to introduce NPs with peripheral thematic roles into the clause; for instance, an instrument in (37). Metma cannot be used an independent clausal predicate.

$\begin{array}{lllll}\mathrm{Na} & \text { hemering } & \text { metma } & \text { sal } & \text { 2-u-tukang. } \\ 1 \mathrm{SG} & \text { knife } & \text { OBL } & \text { rope } & \text { 3sG-CAUS-short }\end{array}$

'I shorten the rope with a knife.'

Historically, metma is composed of two verbs: met (<medi-t) 'take.PFV', as in (38), and $m a$ 'come', as in (39).

$\begin{array}{lllll}\mathrm{Na} & \text { hemering } & \text { medi-t } & \text { sal } & \text { 2-u-tukang. } \\ 1 \mathrm{SG} & \text { knife } & \text { take-PFV } & \text { rope } & \text { 3SG-CAUS-short }\end{array}$

'I shorten the rope using a knife.'

$\begin{array}{llllll}\text { Pana } & \text { BaPalang } & \mathrm{mi} & \text { Melangvala } & \mathrm{mi} & \text { ma. } \\ \text { 3SG } & \text { Baralang } & \text { in } & \text { Melangvala } & \text { in } & \text { come }\end{array}$

'S/he came from Baralang to Melangvala.'

Synchronically, metma is an unanalysable morpheme in Blagar. This is seen from the fact that a second 'give' construction exists, where $m a$ 'come' is used in serialisation with metma, as illustrated in (40). Such doubling would presumably not be possible if metma were not fused.

$\begin{array}{lllllll}\mathrm{Na} & \text { vet } & \text { nu } & \text { metma } & \text { ma } & \text { n-o?al } & \text { 1-enang. } \\ \text { 1SG } & \text { coconut } & \text { one } & \text { OBL } & \text { come } & \text { 1SG-child } & \text { 3SG-give }\end{array}$

'I come with a coconut and give it to my child'

Thus, Blagar monotransitive -enang 'give' has developed into a morphologically complex ditransitive verb by combining with the morpheme metma ' $\mathrm{OBL}$ ' < 'take-come'. The derived ditransitive verb requires a third participant, which is flagged by metma. 
TEIWA

In Teiwa, 'give' events employ the verbs $m a$ 'come' and -an 'give'. Inanimate T's are flagged with $m a$ 'come', while $\mathrm{R}$ is encoded with a prefix as the object of -an 'give'. ${ }^{8}$ For instance:

$\begin{array}{lllllll}\text { Uy } & \text { ga'an } & \mathrm{u} & \text { sen } & \text { ma } & \text { n-oma? } & \text { g-an. } \\ \text { person } & \text { 3SG } & \text { DIST } & \text { money } & \text { come } & \text { 1SG-father } & \text { 3sG-give }\end{array}$

'That person gave money to my father.'

When $\mathrm{T}$ is anaphorically retrievable, it can be omitted. However, $m a$ is not elided. That is, regardless of whether $\mathrm{T}$ is expressed in the clause or not ma must be expressed alongside -an. So, while (42a) with $m a$ is grammatical, (42b) without it is not.

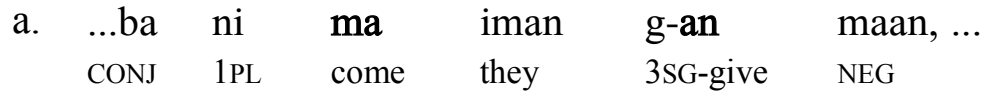

$$
\begin{aligned}
& \text { '[...] so we didn't give (it) to them, ...' }
\end{aligned}
$$

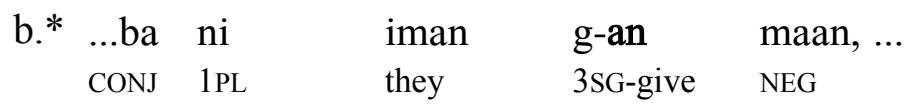

Synchronically, Teiwa $m a$ 'come' has several functions: it occurs as an independent verb in (43); or as an oblique NP marker introducing, for instance, instruments, sources, goals, and locations; ${ }^{9}$ an instrument is illustrated in (44) (see Klamer 2010a: 324-338, 2010b for discussion of full range of oblique functions).

$$
\begin{aligned}
& \text { HaPan la ma le na?an la wa? } \\
& \text { 2SG FOC come or I FOC go }
\end{aligned}
$$

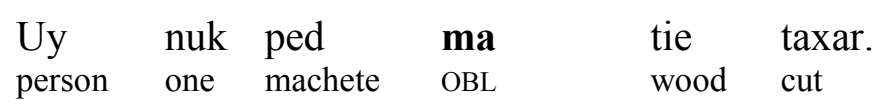

'Someone cuts wood with a machete'

There is a notable syntactic difference between these uses: as an independent verb $m a$ is a monovalent verb with an agentive participant, which can occur in clause-final position and take an inflectional realis suffix, as in (45). As an oblique marker ma takes a complement NP with a non-agentive referent, occurs in non-final position, and cannot be inflected, as in (46). (To distinguish the latter function from its use as a verb 'come', the gloss OBL is used.)

\footnotetext{
${ }^{8}$ Note that when T is animate, a construction is used that involves a SVC with the verb pin 'hold' encoding T and the verb -mian 'put at someone' encoding R. As there are no parallels to this construction in other TAP languages, we do not discuss it further here; see Klamer (2010a: 176-181, 2010c: 446-447) for further information.

${ }^{9}$ Malchukov (2010: 188-189) notes that this polysemy of case markers for instruments and goals is typologically unusual but that the origin of this marker as an early, contextual grammaticalization of the verb ma 'come' presents an explanation.
} 
$\begin{array}{lllll}\mathrm{Na} & \text { tehel } & \text { non } & \text { pin } & \text { ma-n. } \\ 1 \mathrm{SG} & \text { tile } & \text { PL } & \text { take } & \text { come-REAL }\end{array}$

'I bring all the tiles'

\begin{tabular}{|c|c|c|}
\hline A & kamar & $\mathrm{m}$ \\
\hline
\end{tabular}

'He sits in the room'

In Teiwa, we also find 'give' constructions with a bare T. However, these only occur in elicitation through Indonesian, as in (47). This limitation suggests that such bare $\mathrm{T}$ constructions are calques of Indonesian.

$\begin{array}{llllll}\text { Uy } & \text { gaPan } & \mathrm{u} & \text { sen } & \text { n-oma? } & \text { g-an. } \\ \text { person } & \text { 3SG } & \text { DIST } & \text { money } & \text { 1SG- father } & \text { 3SG-give } \\ \text { 'That person gives my father money.' }\end{array}$

In sum, Teiwa 'give'constructions distinguish between animate and inanimate Ts, and the reflex of Proto-TAP 'give' only combines with Ts that are inanimate. The verb has developed into a ditransitive predicate consisting of the verb root - an 'give' and an obligatory particle ma.

\section{SUMMARY OF AlOR PANTAR ‘GIVE’ CONSTRUCTIONS}

All the Alor Pantar languages discussed in the previous sections have more than one strategy to encode a 'give' event. Most generally attested is the 'give' construction involving a medial verb 'take' encoding $\mathrm{T}$ as its complement without any agreement prefixes, and a final verb 'give' encoding $\mathrm{R}$ with an agreement prefix on the verb. 'Take' and 'give' typically occur in a serial verb construction, in which 'take', and not 'give', may undergo semantic bleaching and syntactic reduction to become a light verb or particle that marks obliques. In some languages (Klon, Western Pantar, Abui) the verbs 'take' and 'give' may alternatively form separate clauses connected by a conjunction. A number of languages (Klon, Western Pantar, Blagar, Teiwa) have 'give' constructions involving an additional verb 'come', which may function as a conjunction and follows 'take'. The resulting 'take-come' sequence shows different patterns of formal reduction in the various languages. Constructions with bare or unflagged Ts are also attested (Klon, Western Pantar, Abui and Teiwa), but in all cases these constructions are more marginal and less frequent than the serial verb constructions.

\section{2 'Give' in Timor}

In this section we examine the encoding of 'give' events in the four Papuan languages of Timor. Table 7 presents an overview of the forms under discussion. 


\begin{tabular}{lll}
\hline & $\begin{array}{l}\text { 'TAKE' } \\
<\text { Proto-Timor *mei 'take' }\end{array}$ & 'GIVE' \\
& < Proto-Timor *-in(a/i) 'give' \\
\hline Fataluku & $m e$ & ina \\
Makasae & $m a$ & gini \\
Makalero & $m e i, m-$ & - ini \\
Bunaq & -- & $\{-e g e\} \dagger$ \\
\hline & Table 7: Forms used in Timor 'give' constructions and their etymologies \\
& \multicolumn{2}{c}{$\dagger$ Non-cognate forms are in curly brackets ' \{\}}
\end{tabular}

We highlight: (i) the possibility of double reflexes of Proto-Timor *mei 'take' ( $<$ Proto-TimorAlor-Pantar *med 'take') encoding $\mathrm{T}$ in the Eastern Timor (ET) languages; and (ii) the development of one reflex of *mei into a morpheme bound to the 'give' verb in Makalero. We further note the typologically aberrant 'give' construction found in Bunaq.

\section{FATALUKU}

The Fataluku 'give' verb consists of $m e$ 'take' followed by ina 'give'. R occurs directly before ina, and $\mathrm{T}$ directly before $m e$. Whilst ina never appears independent of $m e$, me can occur as an independent clausal predicate, as in (48).

$$
\begin{aligned}
& \begin{array}{l}
\text {... umani }=\mathrm{t} \text { taratori } \\
\text { who }=\mathrm{SEQ} \\
\text { tractor }
\end{array} \\
& \text { '... who takes the tractor.' }
\end{aligned}
$$

In Fataluku, the 'give' construction is monoclausal. Both verbs share scope for negation and aspect. These markers precede the 'take' verb and its NP, as for instance is illustrated with the negator akam in (49). ${ }^{10}$

$\begin{array}{lllll} & & \text { T } \quad \text { TAKE } & \text { R } & \text { GIVE } \\ \text { Markus } & \text { akam } & \text { lepuru }=\mathrm{m} & \text { an } & \text { ina. } \\ \text { Markus } & \text { NEG } & \text { book=take } & \text { 1sG.OBL } & \text { give } \\ \text { 'Markus didn't give me the book.' } & & \end{array}$

Consistent with a monoclausal analysis is the impossibility of the two verbs in the give construction being coordinated into separate clauses by $=t(u)$ 'SEQ' or $=n$ 'SIM' to mark $m e$ (50). The only way to have a biclausal structure is to repeat $m e$ in a separate clause. This is illustrated in (51) where the two clauses are coordinated by $=t(u)$ 'SEQ'. Me occurs as the final verb of the first clause, and ina as the final verb of the second clause alongside me marked with a pronominal resumptive prefix $e$ - which is coreferent with the T of $m e$ in the previous clause.

\footnotetext{
${ }^{10} \mathrm{Me}$ also has a variant eme (or its allomorph $\mathrm{em}$ ), which is optionally used where the nominal complement of $m e$ is elided (i.e., $e$ - has an anaphoric function). However, $m e$ is never reduced when it is the main, clause-final verb.
} 


\begin{tabular}{|c|c|c|}
\hline$(50)^{*}$ & & $\begin{array}{l}\text { lepuru } \\
\text { book }\end{array}$ \\
\hline
\end{tabular}

'Markus gave me the book.'

$\begin{array}{llllll} & \mathrm{T} & \text { TAKE } & \text { T-TAKE } & \mathrm{R} & \text { GIVE } \\ \text { Markus } & \text { lepuru } & \text { me }=\mathbf{t} & \text { e-m } & \text { an } & \text { ina. } \\ \text { Markus } & \text { book } & \text { take=SEQ } & \text { it-take } & \text { 1SG } & \text { give }\end{array}$

'Markus takes the book and then gives it to me.'

Doubling of me, however, is not limited to biclausal constructions but can also take place in monoclausal 'give' constructions, as in (52). The monoclausality of this clause is signalled by the inclusion of the first three verbs under a single intonation contour without break or pause (section 2.1). 'Comma' intonation can only occur between the two 'take' verbs where a sequence marker such as the one in (51) is included. The fact that it is synchronically possible to double the 'take' verb in a single Fataluku clause is important for the historical analysis of the 'give' constructions in two other Timor languages, Makasae and Makalero, discussed in the following sections.

$\begin{array}{llllll}\text { T } & \text { TAKE } & \text { T-TAKE } & \text { GIVE } & & \\ \ldots \text { mace-nu } & \text { me } & \text { e-me } & \text { ina } & \text { tu } & \text { una. } \\ \text { eat-NMLZ } & \text { take } & \text { it-take } & \text { give } & \text { SEQ } & \text { eat } \\ \text { '... give food to eat.' } & & & & \end{array}$

In short, Fataluku has what at first appears to be a serialisation construction. In the final analysis, we see, however, that the 'take' verb has been brought into the VP, with the result that the T can be doubly marked by 'take'.

\section{MAKASAE}

The Makasae 'give' verb is a complex ditransitive predicate consisting of the particle ma 'OBL' and gini 'give'. Historically, Makasae ma reflects Proto-Timor *mei 'take', ${ }^{11}$ but synchronically it is used as an oblique marker to introduce NPs with peripheral thematic roles, such as instruments, into a clause, as in (53).

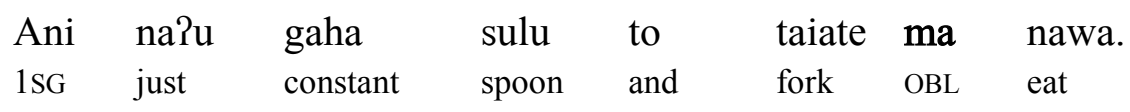

'I always eat with a spoon and a fork.'

\footnotetext{
${ }^{11}$ Makasae ma reflects Proto-Timor *mei 'take' < Proto-Timor-Alor-Pantar *med 'take'. The expected reflex of Proto-Timor *mei in Makasae is *mai. The reduction of expected *mai to ma probably accompanied its development into an oblique marker, in much the same way as the Kamang light verb $m e$ is derived from the full verb met 'take' (section 3.1). Note that the oblique particle ma used in Teiwa 'give' constructions (section 3.1) has a different etymology (< Proto-Alor-Pantar *ma 'come', see Table 6).
} 
Gini occurs clause finally and is invariable in form. ${ }^{12}$ The $\mathrm{R}$ occurs directly in front of gini, while $\mathrm{T}$ precedes $m a$ as in (54a). Ma cannot be omitted. Where $\mathrm{T}$ is not expressed, ma must still be present in the clause $(54 b)$.
a. Markus ira ma
Markus water OBL
'Markus gave me water.'
TAKE
ma
OBL
er.'
T TAKE
b. Markus
$\varnothing$
ma
'Markus gave me (water).'
R GIVE
ani
gini.

Makasae $m a$ cannot be said to 'flag' $\mathrm{T}$, since it does not form a phrase with $\mathrm{T}$. Rather, ma is a constituent of the VP along with R and gini. This is seen in two points: (i) the negator to and adverbs occur between $\mathrm{T}$ and $m a$, and not before or after them, as would be expected if they were in a phrase together, as in (55) and (56); and (ii) $\mathrm{T}$ is fronted without $m a$, as illustrated in (57a) and (57b).

$\begin{array}{llllll} & \text { T } & \text { TAKE } & \text { TAKE } & \text { R } & \text { GIVE } \\ \text { Ani } & \text { surat } & \text { to } & \text { ma } & \text { Markus } & \text { gini. } \\ \text { 1SG } & \text { book } & \text { NEG } & \text { OBL } & \text { Markus } & \text { give }\end{array}$

'I didn't give Markus a book.'

$\begin{array}{lllllll} & & \text { T } & & \text { TAKE } & \text { R } & \text { GIVE } \\ \text { Ani } & \text { ni } & \text { surat } & \text { taPate } & \text { ma } & \text { Markus } & \text { gini. } \\ \text { 1SG } & \text { REFL } & \text { book } & \text { temporarily } & \text { OBL } & \text { Markus } & \text { give }\end{array}$

'I temporarily gave Markus a book.'
$\mathrm{T}$
a. Surat ere asi bada $\mathrm{u}$ ini book DEM 1sG.POSS friend one one $\quad$ SUBJ

$\begin{array}{lll}\text { TAKE } & \text { R } & \text { GIVE } \\ \text { ma } & \text { ani } & \text { gini. } \\ \text { OBL } & 1 \mathrm{SG} & \text { give }\end{array}$
'My friend gave me the book.'

\begin{tabular}{|c|c|c|c|c|c|c|c|}
\hline b. $\begin{array}{l}\text { Surat } \\
\text { book }\end{array}$ & $\begin{array}{l}\text { ere } \\
\text { DEM }\end{array}$ & $\begin{array}{l}\mathrm{ma} \\
\mathrm{OBL}\end{array}$ & $\begin{array}{l}\text { asi } \\
\text { 1SG.POSS }\end{array}$ & $\begin{array}{l}\text { bada } \\
\text { friend }\end{array}$ & $\begin{array}{l}\mathrm{u} \\
\text { one }\end{array}$ & $\begin{array}{l}\text { ini } \\
\text { SUBJ }\end{array}$ & $\begin{array}{l}\text { ani } \\
1 \mathrm{SG}\end{array}$ \\
\hline
\end{tabular}

When occurring in a 'give' construction with gini 'give', oblique ma can be optionally doubled. This occurs in two situations: (i) when R is elided, as in (58), or (ii) when R is fronted, as in (59). Such doubling of $m a$ is reminiscent of the doubling of $m e$ 'take' attested in Fataluku (but unlike Fataluku me, Makasae ma cannot act as an independent predicate). In these instances, the right-

\footnotetext{
${ }^{12}$ Historically, gini represents the root -ini with a fossilised $3^{\text {rd }}$ person agreement prefix; cognate with Makalero kini, see below.
} 
hand $m a$ is part of the VP, while the left-hand $m a$ acts as a place-holder for the elided or fronted $\mathrm{R}$, hence the possibility of doubling $m a$ when encoding a $\mathrm{T}$, but no other argument (e.g., an instrument like that in 53).

$\begin{array}{lllll} & \text { T } & \text { TAKE } & \text { TAKE } & \text { GIVE } \\ \text { Ani } & \text { susuwehe } & \text { ma } & \text { ma } & \text { gini. } \\ \text { 1SG } & \text { milk } & \text { OBL } & \text { OBL } & \text { give }\end{array}$

'I give (him) milk.'

$\mathrm{R}$

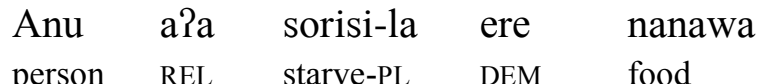

'To the hungry food will be given.'

\section{T TAKE TAKE GIVE}

ma ma gini.

OBL OBL give

Thus, Makasae displays similar ditransitive behaviour to what we have seen in Fataluku. That is, both languages allow double marking of the T. The only difference is that Makasae ma is an oblique case marker, while Fataluku $m e$ is still a full lexical 'take' verb.

\section{MAKALERO}

The Makalero 'give' constructions are formed around the verb root -ini 'give', where a pronominal prefix encoding $\mathrm{R}$ is prefixed with $m$-, see Table 8 . The absence of the initial $m$ - on the $3^{\text {rd }}$ person and $1^{\text {st }}$ person inclusive reflects a restriction on onset clusters $* / \mathrm{mk} /, * / \mathrm{mf} /$.

\begin{tabular}{lllll}
\hline & Free pronouns & $\begin{array}{l}\text { Underlying } \\
\text { 'give' }\end{array}$ & Surface 'give' & Meaning \\
\hline MSG & ani & $m$-R-GIVE & \\
$2 \mathrm{SG}$ & $e i$ & $m$-ei-ini & manini & 'give to me' \\
3 & $k i$-loo(ra) & $\varnothing$-ki-ini & kini & 'give to you' \\
1 PL.EXCL & ini & $m$-ini-ini & minini & 'give to him/her/it/them' \\
1 PL.INCL & $f i$ & $\varnothing$-fi-ini & fiini & 'give to us' \\
2 PL & $i i$ & $m$-ii-ini & miini & 'give to you' \\
\hline & Table 8: Makalero free pronouns and inflections of 'give' (Huber 2011: 207, 406-407)
\end{tabular}

Whilst R (with the element $m$ - prefixed to it) is incorporated into the VP, T is coded as a separate constituent. This may be done in one of two ways: (i) $\mathrm{T}$ can be a second, bare argument of -ini 'give', as in (60), ${ }^{13}$ or (ii) T can be flagged in the clause with $m e i$ 'take'. Flagging of T with mei may occur in the same clause as $-i n i(61)$, or in a separate clause conjoined with $=n i(62)$.

\footnotetext{
${ }^{13}$ In (53) muni 'return' is an intransitive verb that is used in serial verb constructions to denote the reversal of an action's direction. For example, the reversal of the action of 'walking to the village' would be 'to walk back from the village'. Here, it serializes with 'give' to denote 'to give back'.
} 
$\mathrm{T}$

...asi-osan hai

1SG.POSS-money NSIT

'... (he) gave my money back to me...'

$(61)$

$\begin{array}{ccl}\text { T } & \text { TAKE } & \text { TAKE-R-GIVE } \\ \text {..., ho?o } & \text { mei } & \text { m-an-ini. } \\ \text { some take } & \text { M-1sG-give } \\ \text { ‘.., give some to me.' }\end{array}$

$(62)$

$\begin{array}{lllll} & \text { T } & \text { TAKE } & \text { R } & \text { TAKE-R-GIVE } \\ \text { Kiloo } & \text { seur } & \text { mei }=\text { ni } & \text { sefar } & \emptyset \text {-k-ini. } \\ \text { 3SG } & \text { meat } & \text { take=CONJ } & \text { dog } & \text { M-3-give } \\ \text { 'He gives meat to the dog.' } & & \end{array}$

In sum, Makalero has three 'give' constructions. Two are monoclausal: one with a bare T, and the other with $\mathrm{T}$ as the complement of 'take'; and one is biclausal.

BUNAQ

In Bunaq, the synchronic 'give' verb, -ege, does not reflect Proto-Timor-Alor-Pantar *en(a/i) 'give'. All three arguments of -ege are realised as simple NPs. In unmarked word order, R occurs directly before the verbs and is co-indexed on the verb by an agreement prefix, while $\mathrm{T}$ follows the verb. This is illustrated in (63). Bunaq is the only Timor-Alor-Pantar language with $\mathrm{T}$ in postverbal position (cf. (1e)).

$\begin{array}{llll} & \text { R } & \text { R-GIVE } & \text { T } \\ \text { Neto } & \text { Markus } & \text { g-ege } & \text { paiol. } \\ \text { 1SG } & \text { Markus } & \text { 3AN-give } & \text { corn } \\ \text { 'I gave Markus corn.' } & & \end{array}$

The modern Bunaq reflex of Proto-Timor *in(a/i) 'give' is -ini 'CAUS'. Synchronically it is not used as a transfer verb 'give', but rather expresses causative meaning, as in (64) and (65). Bunaq -ini has three arguments, like -ege 'give', but -ini differs in that one of its arguments (corresponding to $\mathrm{T}$ in the case of -ege) is not an NP but itself an argument-taking predicate. That is, -ini has the following argument structure <causer, causee, PRED $>$, where the S/A of the predicate denoting the caused event is coreferent with the causee argument.

$\begin{array}{llllll}\text { Markus } & \text { n-ini } & \text { he } & \text { zemal } & \text { Lakus } & \text { gene. } \\ \text { Markus } & \text { 1EXCL-CAUS } & \text { run } & \text { go.down } & \text { Laku } & \text { LOC }\end{array}$

'Markus made me run down to Lakus.'

\footnotetext{
${ }^{14}$ We analyse the prefix $m$ - in the Makasae examples as a reflex of the Proto-Timor verb *mei 'take', and cognate with verbal $m e$ in Fataluku and oblique ma Makasae; an account is presented below.
} 


$\begin{array}{lllllll}\text { Eme } & \text { Yati } & \text { g-ini } & \text { n-ege } & \text { buku } & \text { bari } & \text { teni. } \\ \text { mother } & \text { Yati } & \text { 3AN-CAUS } & \text { 1EXCL-give } & \text { book } & \text { DEM } & \text { again } \\ \text { 'Mother made } & \text { Yati give me this book again.' }\end{array}$

Bunaq thus has two trivalent verbs, the transfer verb -ege and the causative verb -ini, whose three arguments are syntactically treated in the same way, as summarised in (66).

$$
\begin{array}{llll}
\text { A } & \mathrm{R} & \mathrm{R}-\mathrm{V} & \mathrm{T} \\
\operatorname{giver}_{\mathrm{NP}} & \text { givee }_{\mathrm{NP}} & - \text { ege } & \text { gift }_{\mathrm{NP}} \\
\text { causer }_{\mathrm{NP}} & \text { causee }_{\mathrm{NP}} & -i n i & \text { caused }_{\text {PRED }}
\end{array}
$$

In short, the 'give' construction in Bunaq differs from the 'give' constructions in the other Timor languages in both verbal etymology and constituent order.

\section{SUMMARY OF TIMOR ‘GIVE’ CONSTRUCTIONS}

The 'give' constructions in Timor languages discussed in this section fall into two groups. On the one hand there is Bunaq, which has a bare $\mathrm{T}$ construction that is aberrant in verbal etymology as well as constituent order. On the other hand there are the Eastern Timor languages, Fataluku, Makalero and Makasae, whose 'give' constructions involve (reflexes of) a serial verb construction with the verb 'take' introducing $\mathrm{T}$, and a final verb 'give' introducing $\mathrm{R}$; structurally similar to those found in Alor-Pantar.

Unlike the Alor-Pantar languages, however, the Eastern Timor languages may use double reflexes of 'take' to flag T. Makalero has a synchronic bare T-construction, but as this involves the historical incorporation of mei 'take' as a prefix on the 'give' verb, its history is unlike the bare $\mathrm{T}$ constructions in Alor-Pantar.

\section{Reconstruction and History of 'Give' Constructions}

In the previous section we have seen that the majority of modern Timor-Alor-Pantar languages employ a 'give' construction which involves a non-final verb 'take' flagging T, and a verb 'give' with a prefix referring to R. We suggest that these constructions go back to the following two constructions in Proto-Timor-Alor-Pantar (PTAP) in (67), repeated from (2).

$$
\begin{array}{lllll}
\text { PTAP 'give' constructions } & & & \\
\text { Monoclausal: } & \mathrm{A}_{\mathrm{NP}} \mathrm{T}_{\mathrm{NP}} \text { TAKE } & \text { R } & \mathrm{R}_{\mathrm{AGR} \text {-GIVE }} \\
& \text { 'A gives T to R' } & & \\
\text { Biclausal: } & \mathrm{A}_{\mathrm{NP}} \mathrm{T}_{\mathrm{NP}} \text { TAKE CONJ } & \mathrm{R}_{\mathrm{NP}} & \mathrm{R}_{\mathrm{AGR} \text {-GIVE }} \\
& \text { 'A takes T and gives to R' } & &
\end{array}
$$

We reconstruct both a biclausal and monoclausal construction for the following reasons. Reconstruction of the biclausal construction is supported by its presence in three modern languages representing both primary subgroups of the family, in Klon and Abui (AP subgroup) and in Makalero (Timor subgroup). Reconstruction of the monoclausal construction alongside the biclausal one is supported by the fact that there is no TAP language with only the biclausal construction and not also the monoclausal one. That the biclausal structure is so infrequently 
maintained in the modern languages points to a strong preference of the TAP languages to encode 'give' events in a monoclausal construction.

In addition to reconstructing the 'give' constructions, we find we can also reconstruct the verb forms used in them. TAP 'give' constructions generally employ reflexes of both PTAP *med 'take', and PTAP *-en(a/i) 'give'. There are three exceptions. In Western Pantar, etymological *med has been replaced by haggi 'take', while in Abui *-en(a/i) has been replaced by $-r \sim-l$ 'give'. ${ }^{15}$ In each case, the monoclausal construction in (67) is maintained despite the lexical replacements. Only one language, Bunaq, lacks both a 'give' construction reflecting those in (67) and a lexical reflex *med 'take'.

In the following sections, we present an analysis as to how the variety of modern constructions with the 'give' verb arose in the TAP languages by describing the development of 'give' constructions from the proto-construction given in (67). Our discussion focuses on the encoding of $\mathrm{T}$, in particular, the reanalysis of the morpheme flagging the $\mathrm{T}$ constituent (section 4.1), the development of fixed particle-verb combinations to express 'give' events (section 4.2), the fusion of the verb 'take' with the verb 'give'(section 4.3), and the development of bare T constructions (section 4.4).

\subsection{Development of the verb 'come' into a T-flagging particle}

In this section, we describe how the verb 'come' developed into a T-marking particle in the 'give' constructions in Alor and Pantar. In AP languages, there is a common pattern in which the verb 'come' (< PAP *ma) is used to connect events. ${ }^{16}$ Examples of this use of 'come' are given for Kamang (68), Teiwa (69), and Klon (70). In these, 'come' is functionally a conjunction-like element linking sequential events.

Kamang

$$
\begin{array}{llll}
\text { Kui=a } & \text { ga-buh } & \text { me } & \text { wo-pakah. } \\
\text { dog=ART } & \text { 3.PAT-lift } & \text { come } & \text { 3.LOC-embrace }
\end{array}
$$

'(He) lifts up the dog and cuddles him.'

Teiwa

$\begin{array}{lllllll}\text { Bif } & \text { g-oqai } & \text { nuk } & \text { bir-an } & \text { ma } & \text { h-oqan } & \text { tas. } \\ \text { child } & \text { 3s-child } & \text { one } & \text { run-REAL } & \text { come } & \text { 2SG-hug } & \text { stand }\end{array}$

'His child runs and hugs you'

Klon

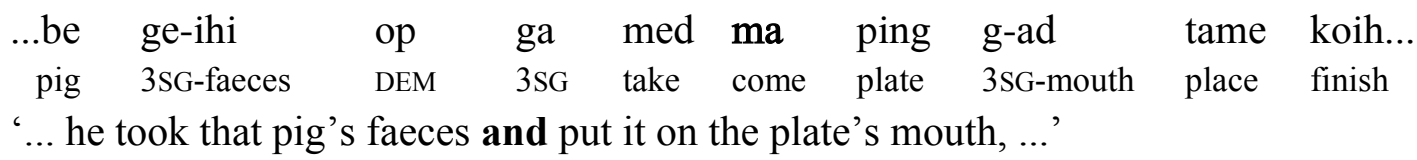

\footnotetext{
${ }^{15}$ The Abui 'give' innovation appears to have been sourced from a benefactive marker (meaning something like 'to do/be for X') which is reflected in several other languages, e.g., Western Pantar - $r$ 'BEN'.

${ }^{16}$ Klamer $(2010 \mathrm{a}, \mathrm{b})$ refers to this kind of serialisation with 'come' in Teiwa as describing a 'movement in space or time'. Schapper (n.d.) refers to it as 'turn of events serialisation'.
} 
Historically, such 'conjunctive' uses of 'come' have resulted in the development of AP 'give' constructions with the verb 'come'. The putative stages leading up to the modern constructions with 'come' are set out in (71). Explanations of each stage are found below.

\begin{tabular}{|c|c|c|c|c|}
\hline \multicolumn{5}{|c|}{ Development of verbal 'come' to flagging of $\mathrm{T}$ in Alor Panta } \\
\hline Proto-TAP & A $\mathrm{T}$ & TAKE & $\mathrm{R}$ & R-GIVE \\
\hline STAGE I & A $[\mathrm{T}$ & take $]_{\mathrm{VP}}[\text { come }]_{\mathrm{CONJ}}$ & {$[\mathrm{R}$} & ve]] \\
\hline STAGE II & A $[[\mathrm{T}$ & take $]_{\mathrm{VP}}$ come $]_{\mathrm{XI}}$ & {$[\mathrm{R}$} & R-give] \\
\hline STAGE IIIA & A $[\mathrm{T}$ & take-come $]_{\mathrm{XP}}$ & {$[\mathrm{R}$} & R-give] \\
\hline STAGE IIIB & $\mathrm{A}[\mathrm{T}$ & $\varnothing$ come $]_{\mathrm{XP}}$ & {$[\mathrm{R}$} & R-give] \\
\hline
\end{tabular}

In StAge I we posit that 'come' was used productively as a pseudo-conjunction in a serial verb construction - recall that biclausal 'give' constructions were historically also possible. 'Come' in this stage is an independent intransitive verb that is neither subordinate nor coordinate to the two transitive verbs involved in a 'give' event, each forming a separate phrase with their complement. Examples of languages where this construction is attested are Klon and Western Pantar.

In Stage II, a reanalysis takes place whereby 'come' forms a syntactic phrase with the preceding 'take' verb. Note that this change is consistent with the previous conjunction-like status of 'come', since conjunctions in the head-final AP languages typically associate with a preceding constituent. An example of a language with this construction attested is Klon.

After 'come' has been incorporated into the 'take'-phrase, two alternative developments are observed. In STAGE IIIA, 'come' prosodically attaches to 'take', and together the two verbs then form a single word 'take-come' that functions as oblique marker of T. Blagar (metma 'OBL' < met 'take', $m a$ 'come'), represents this stage of development.

In STAGE IIIB, the phrase [T take come] is reduced to [T $\varnothing$ come]. The verb 'come' now functions as oblique marker of T. This stage is represented by Teiwa ( $m a$ 'OBL'), which has it as its only option; and in Western Pantar and Klon, which have 'come' optionally occurring between 'take' and 'give', and then allow 'take' to be omitted, such that 'come' has become the flagging of $\mathrm{T}$.

While the 'give' constructions in stage IIIA and IIIB can (and often do) project two distinct syntactic phrases (one with the $\mathrm{T}$ argument, the other with the $\mathrm{R}$ ), lexically, they are a single unit. The lexical unit is a ditransitive verb which consists of two separate lexemes: a T marking particle (etymologically either 'take-come' or 'come') and a root verb 'give'.

\subsection{Development of particle-verb predicates for 'give'}

In section 3.1 we saw that in Kamang, Teiwa, Blagar and Makasae, the particle (or light verb) that is used to flag $\mathrm{T}$ historically derives from the verbs 'take' or 'come', or from a combination of these.

The differences between its use as an independent verb on the one hand, and as a T-flag on the other, are that in its T-flagging function the word cannot take any verbal inflections. In fact, it has lost most of its verbal semantics and developed into an element that is used to flag various kinds of oblique NPs. For instance, the Kamang light verb me 'TAKE' flags T in (72a) and an instrument in (72b): 

a. $\mathrm{Na}$
$\begin{array}{ll}\text { bong } & \text { ga-tang } \\ \text { tree } & 3 \text { PAT-hand }\end{array}$
me
ge-n.
1SG.AGT
3.PAT-hand
TAKE
3.GEN-give

'I gave the branch to him.'

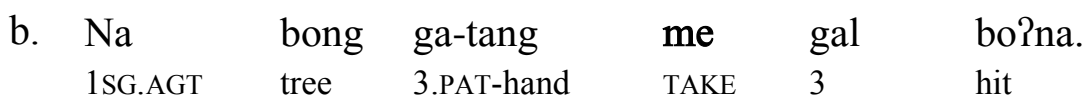

'I hit him with the branch.'

There is, however, a crucial difference between the T constituent in a 'give' event and an adjunct NP. Adjunct NPs are syntactically optional: as non-core arguments they can be omitted from a clause without problem. By contrast, a $\mathrm{T}$ in a 'give' event is a core argument of a ditransitive verb. It is syntactically obligatory along with the particle that marks it. That is, even when $\mathrm{T}$ is not expressed, it is an obligatory argument of the verb (cf. examples (31a-b) and (42a-b) above).

In other words, the 'give' predicate is a separable complex verb: a verb consisting of two parts that form a single lexical unit, but are not morpho-phonologically integrated and can project different syntactic phrases. Such separable complex predicates (also referred to as particle-verb combinations) occur in many languages ${ }^{17}$ and form a subset of the class of phrasal verbs discussed in Ackermann and Webelhuth (1998).

We posit that the particle-verb combinations in the individual languages arose through semantic bleaching and subsequent syntactic reanalysis of the verb 'take', as laid out in (73).

$$
\begin{aligned}
& \text { Reanalysis of 'take' in TAP 'give'-encodings } \\
& \text { StAGE I A }\left[\begin{array}{llll}
\mathrm{T} & \text { take(-come })]_{\mathrm{VP}} \quad[\mathrm{R} & \mathrm{R} \text {-give }]_{\mathrm{VP}}
\end{array}\right. \\
& \text { StAGE II A }\left[\begin{array}{llll}
\mathrm{T} & \text { take(-come) } & {[\mathrm{R}} & \mathrm{R} \text {-give }
\end{array}\right]_{\mathrm{VP}}
\end{aligned}
$$

In Stage I, $\mathrm{T}$ and $\mathrm{R}$ are part of distinct verb phrases. This stage is still occupied by modern languages such as Klon and Western Pantar, which do not require that the T-flagger be part of the same clause as the 'give' verb.

In Stage II, the marker of T ('take' / 'take-come') is reanalysed as part of the phrase headed by 'give', and becomes an obligatory part of it.

Thus, a historical process of reanalysis explains the syntactic restriction that 'give' constructions in languages such as Kamang, Blagar and Teiwa obligatorily involve two forms: one to flag $\mathrm{T}$ ( $<*$ med 'take' and/or *ma 'come') and one to encode $\mathrm{R}$ ( $<*$-en(a/i) 'give').

Since different T-encoding morphemes are used (<'take', 'come' or 'take-come') the reanalysis must have occurred independently in the individual languages. In the following section, we see that this reanalysis was a precursor to a further reanalysis in the Eastern Timor languages.

\footnotetext{
${ }^{17}$ For instance, a verb like Dutch opbellen 'to phone', is traditionally classified as a separable complex verb; compare ...dat Hans zijn moeder opbelt '... that Hans phones his mother' vs. Hans belt zijn moeder op 'Hans phones his mother', see Booij 1990, Blom and Booij 2003 for an analysis of such predicates in Dutch, and further references.
} 


\subsection{Development of 'take' into a prefix of 'give'}

In section 3.2 we saw that in Eastern Timor languages reflexes of Proto-Timor *mei 'take' (< PTAP *med 'take') could be doubled in clauses denoting 'give' events. Historically, this doubling of 'take' is the result of a further reanalysis of the structure discussed in the previous section, in which the T-flag became an obligatory part of the particle verb 'give'. Subsequent changes leading up to modern Eastern Timor constructions are set out in (74).

\begin{tabular}{|c|c|c|c|c|c|}
\hline \multicolumn{6}{|c|}{ Reanalysis of 'take' in Eastern Timor 'give'-encodings } \\
\hline STAGE I & A & {$[\mathrm{T}$} & take] $]_{\mathrm{VP}}$ & {$[\mathrm{R}$} & R-give $]_{\mathrm{VP}}$ \\
\hline StAGE II & A & {$[\mathrm{T}$} & take & {$[\mathrm{R}$} & R-give] $]_{\mathrm{VP}}$ \\
\hline STAGE III & A & $\mathrm{T}$ & [take & $\mathrm{R}$ & R-give $]_{V P}$ \\
\hline STAGE IV & A & {$[\mathrm{T}$} & take $]_{\mathrm{VP}}[$ take & $\mathrm{R}$ & R-give $]_{v p}$ \\
\hline STAGE V & A & $\mathrm{T}$ & (take) & $\mathrm{R}$ & {$[\text { take-R-give }]_{\mathrm{VP}}$} \\
\hline
\end{tabular}

In the 'take give' serial verb construction (STAGE I), 'take' gradually loses some of its semantics as active 'handling' verb and is reanalysed as T-flag, projecting a phrase that is no longer independent, but must occur in combination with the verb 'give' (STAGE II). In STAGE III, T is licensed by the verbal phrase containing both 'take' and 'give' but $\mathrm{T}$ itself is not syntactically part of this phrase. STAGE IV, with a semantically bleached handling verb 'take', paves the way for the construction set out in STAGE V, where T is flagged by a new lexical handling verb 'take'. The result is a doubling of 'take' forms. In Fataluku and Makasae both STAGE III and STAGE IV 'give' constructions are synchronically attested. STAGE V represents a further development: the reflex of 'take' has been reduced to a single consonant prefix $m$ - that attaches to the 'give' verb (plus inflection). In addition to the bound reflex of 'take' in the VP, an additional (non-reduced) verb 'take' can in Stage V flag $\mathrm{T}$ as per StAGe IV. Makalero is the only language that underwent the developments leading to STAGE V.

\subsection{Development of bare $T$ constructions}

In this section, we discuss the likely origins of 'give' constructions in which $\mathrm{T}$ is unflagged, that is, unmarked by any adpositional or verbal elements in the clause. We refer to this as a bare $T$ construction.

\section{ALOR-PANTAR: T R GIVE}

Bare $\mathrm{T}$ constructions in which both NPs encoding $\mathrm{T}$ and $\mathrm{R}$ precede the 'give' verb are attested in the areally diffuse Alor-Pantar languages Western Pantar, Klon, and Abui. ${ }^{18}$ Bare $\mathrm{T}$ constructions are not attested in any of the Timor languages. We suggest that these constructions are later innovations in the individual AP languages in which they arose. We propose that they arose as shortenings of $\mathrm{T}$-flagging constructions due to pragmatic emphasis on $\mathrm{T}$ and/or influence from the Austronesian contact language, Indonesian/Malay. This is suggested by the following points.

\footnotetext{
${ }^{18}$ Malchukov et al. (2010: 16-18) observe that when NPs encoding $\mathrm{T}$ and $\mathrm{R}$ are unflagged, $\mathrm{R}$ typically precedes $\mathrm{T}$. However, given the secundative morphological alignment of the AP 'give' verbs, we expect R to occur closer to the verb stem (as per Siewierska \& Bakker 2007).
} 
Firstly, in no AP language are 'give' events encoded solely by a construction in which T and $\mathrm{R}$ are unflagged. There is always at least one other construction in which $\mathrm{T}$ is marked by a verb ('take' and/or 'come'). This points to the unflagged constructions as being reductions of constructions where $\mathrm{T}$ is flagged.

Secondly, in each language with the construction it is invariably much less common than one in which $\mathrm{T}$ is flagged. For instance, in Abui out of a corpus with some 50 examples of the 'give' verb, there were only two in which $T$ was unflagged. In Klon, examination of corpus data reveals that 'give' with bare $\mathrm{T}$ is less frequent than both the serialised and biclausal constructions. ${ }^{19}$

What is more, the use of bare $\mathrm{T}$ constructions is often conditioned by certain pragmatically marked situations. For instance, in Western Pantar, T seems to be unflagged most often when it is fronted, i.e., is in focus in the utterance. Similarly, in Abui $\mathrm{T}$ is unflagged only in hortatives and imperatives where NPs encoding both $\mathrm{A}$ and $\mathrm{R}$ are elided.

Finally, in some languages the bare $\mathrm{T}$ construction has not been observed in natural speech at all. For instance, in Teiwa constructions with unflagged $\mathrm{T}$ only occur in elicitation. This suggests that they are calqued from the Indonesian/Malay construction in which $\mathrm{T}$ is also unflagged.

\section{BUNAQ: R GIVE T}

The unflagged post-verbal position of $\mathrm{T}$ in the Bunaq 'give' construction is not only unique amongst the TAP languages, but also otherwise cross-linguistically unattested. Malchukov et al. (2010:16) claim in their survey of ditransitives that the order ARVT does not occur in languages with SV/APV. As such, the origin of the word order in the Bunaq 'give' construction deserves some deliberation here.

Our account of the Bunaq word order goes back to the development of Proto-Timor *in(a/i) 'give' into a causative verb in the Timor languages. A similar development of 'give' into 'causative' is also observed in Makasae gini and Makalero -ini. In these languages, the causative construction is only found with intransitive verbs. In Makasae, the $\mathrm{S}$ of the caused event denoted by the intransitive verb is the $\mathrm{P}$ of the causative verb gini. The intransitive verb can either follow (75a) or precede (75b) the matrix verb. In the Makalero causative construction -ini takes the intransitive verb denoting the caused event instead of the recipient NP that would be its complement when it is used as transfer verb 'give' (see \$2.2); the causee (i.e., the underlying S of the intransitive verb) is flagged with $m e i$ 'take', as in (76).

Makasae
a. Felm felm
wehalapu
ere
ani
$1 \mathrm{SG}$
gini
baruk.
movie $\sim$ REDUP like.that
'Movies like that bore me.'
b. Ani ni tana baga gini.
$1 \mathrm{SG}$ REFL hand wound make
'I hurt my hand', literally, 'I made my hand be wounded.'

\footnotetext{
${ }^{19}$ This seems to contradict Baird (2008:34-35), who suggests that the bare $\mathrm{T}$ construction is the most common coding of 'give' constructions in Klon. However, Baird (2008:124) also states that utterances with three referents are typically expressed as serial verb constructions, which is in line with our observations of the corpus.
} 
Makalero

$$
\begin{aligned}
& \mathrm{Ei}=\mathrm{ni} \quad \text { ani } \quad \text { mei } \quad \text { pa?uk-ini }=\text { si... } \\
& 2 \mathrm{SG}=\mathrm{CTR} \quad 1 \mathrm{SG} \text { take bad-CAUS=SEQ }
\end{aligned}
$$

Unlike Makasae and Makalero, the caused event in Bunaq is not limited to simple intransitive verbs, but has been extended to include fully specified clauses with verbs of any valency plus its arguments, as well as postpositional phrases and adverbials and so forth (see examples in $\$ 2.2$ for illustration of this). Given the possible weight of the clauses denoting the caused event in Bunaq, it is unsurprising that these occur on the left-periphery of the clause with the matrix verb -ini. Languages are well-known to show dispreferences for embedding of one clause within another clause; the heavier the embedded clause, the more likely it is to be moved to the clausal periphery.

Historically, we posit that the Bunaq word order with trivalent verbs, including the synchronic -ege 'give', arose out of just such a dispreference to embed heavy clauses. In (77) we present the stages we see as likely having led up to the modern situation. They are outlined below.

$\begin{array}{lcclll}\begin{array}{l}\text { Development of Bunaq 'give' word order } \\ \text { STAGE I }\end{array} & \text { A } & {[\mathrm{T}]_{\mathrm{NP} / \text { CLAUSE }}} & {[\mathrm{R}} & \mathrm{R}-i n i] & \\ \text { STAGE II } & \mathrm{A} & {[\mathrm{T}]_{\mathrm{NP} / \text { CLAUSE }}} & {[\mathrm{R}} & \mathrm{R}-i n i] & {[\mathrm{T}]_{\text {CLAUSE }}} \\ \text { STAGE III } & \mathrm{A} & {[\mathrm{T}]_{\mathrm{NP} / \text { CLAUSE }}} & {[\mathrm{R}} & \mathrm{R}-i n i] & {[\mathrm{T}]_{\mathrm{NP} / \text { CLAUSE }}} \\ \text { STAGE IV } & \mathrm{A} & & {[\mathrm{R}} & \mathrm{R}-i n i] & {[\mathrm{T}]_{\mathrm{NP} / \text { CLAUSE }}} \\ \text { STAGE VA } & \mathrm{A} & {[\mathrm{R}} & \mathrm{R}-i n i] & {[\mathrm{T}]_{\text {CLAUSE }}} \\ \text { STAGE VB } & \mathrm{A} & {[\mathrm{R}} & \mathrm{R}-e g e] & {[\mathrm{T}]_{\mathrm{NP}}}\end{array}$

In StAge I, -ini was a verb that could be used either as meaning 'give' or 'cause'. When meaning 'give' $\mathrm{T}$ was an NP, and when 'cause' $\mathrm{T}$ was a clause represented by a simple verb. In STAGE II, as the caused event came to be encoded by increasingly heavier clauses, the clause could be postposed to -ini, in addition to occurring before -ini in the same position as NP denoting T. In StAGE III, NPs denoting $T$ could also occur in this postverbal position as well as the preverbal one. Eventually, in STAGE IV, the postverbal position of $\mathrm{T}$ is the only option available for both NPs and clauses. The increasing push towards a post-verbal $\mathrm{T}$ in Bunaq was most certainly aided by the fact that the neighbouring Austronesian languages have a post-verbal T. For instance, in the 'give' constructions of Kemak and Tetun, two Austronesian languages that have had a significant impact of Bunaq (see Schapper 2011a, Schapper 2011b, Schapper 2010: 22-25), the T appears unflagged directly following the verb, while $\mathrm{R}$ is flagged by a preposition, as in (78) and (79).

Kemak (Schapper 2011a: 44)

(78) $\begin{array}{lllll}\mathrm{A} & \text { ne } & \text { buku le } & \text { Markus. } \\ 1 \mathrm{SG} & \text { give book to } & \text { Markus }\end{array}$

'I gave the book to Markus.' 
Tetun (Schapper 2011a: 44)

$\begin{array}{lllll}\mathrm{Ha} 2 \mathrm{lu} & \text { fo buku ba } & \text { Markus. } \\ \text { 1SG give book to } & \text { Markus }\end{array}$

'I gave the book to Markus.'

Finally, in STAGE V, -ini specializes to be a causative verb only, and its $\mathrm{T}$ argument can only be a clause (STAGE VA). At the same time, a new trivalent verb -ege emerges to encode 'give' and this matches the existing word order established by the only other trivalent verb -ini (STAGE VA).

\section{Summary and Conclusions}

This paper has looked in detail at the way $\mathrm{T}$ is encoded in 'give' constructions in the TimorAlor-Pantar languages. With the exception of Bunaq, Timor-Alor-Pantar languages that we have discussed all make use of more than one strategy to encode the T of a 'give' event.

The most generally attested strategy is the serial verb strategy. In this, the lexical 'give' verb is serialised with the verb 'take'. The 'take' verb introduces the T and the verb 'give' encodes R, minimally by means of a prefix. In some languages of Alor, such as Abui and Kamang, the verb 'take' has been syntactically demoted to a particle that is obligatorily licensed by the use of the final 'give' verb. In these languages, the particle derived from 'take' must appear with the 'give' verb, even where the NP referring to T is elided, in order for the utterance to be grammatical. The particle may only be omitted in very pragmatically (if there is discourse focus on the identity of the referent of T) and syntactically marked situations (if the $\mathrm{T}$ is fronted and the NP for R elided).

In the languages of Pantar and West Alor discussed here, a third verb 'come' has been introduced into 'give' constructions, positioned between the 'take' and 'give' verbs. Subsequently, the collocation of 'take come' has grammaticalised into a complex T-flagging particle. Different T-encoding morphemes ('come' and 'take-come') are attested, indicating that the grammaticalisation path (<'take', <'take-come', <'come') must have occurred in several individual languages. Synchronically, the particles originating from 'take', 'take-come' or 'come' either constitute an oblique particle encoding adjuncts (e.g. in Teiwa) or a complex verb with 'give' (e.g. in Blagar). Several Alor-Pantar languages also express a 'give' event not only as a serialisation but also as a biclausal construction; and in some of the languages bare $\mathrm{T}$ constructions are attested alongside serialisations or particle verb constructions. In our analysis, the biclausal construction already existed in the proto-language, while bare $\mathrm{T}$ constructions are either reductions from serialisations or particle verbs; or calques from Indonesian.

Some grammatical changes are unique for the Timor languages Fataluku, Makalero and Makasae: the use of double reflexes of 'take' to flag T, and the lack of bare T constructions. Within the TAP family as a whole, the Timor language Bunaq is aberrant in both verbal etymology as well as constituent order.

In sum, 'give' constructions in Timor-Alor-Pantar languages show a great consistency in the treatment of ditransitive $R$ while it is the ditransitive $T$ which shows a surprising amount of diversity in its treatment from language to language. In this paper, we have shown that what - on first glance and on the basis of existing descriptions - appear to be (near-)identical constructions can be subtly distinguished by the application of fine syntactic tests and by the careful consideration of corpus data. In doing this, we have been able to reconstruct the history of 'give' constructions in Timor-Alor-Pantar languages and draw attention to the different stages of 
grammaticalisation which different languages in the family have reached. As such, we have not only brought to light a range of 'give' constructions that are new to typology, but we have also explained how these types have come into being.

\section{References}

Ackerman, Farrell and Gert Webelhuth. 1998. A theory of predicates. Stanford, California: CSLI Publications.

Baird, Louise. n.d. Klon corpus. Leiden University.

-----. 2005. Doing the split-S in Klon. Linguistics in the Netherlands 2005, ed. by Jenny Doetjes and Jeroen van de Weijer, 1-12. Amsterdam: John Benjamins.

-----. 2008. A grammar of Klon. Canberra: Pacific Linguistics.

Blom, Corrien and Geert Booij. 2003. The diachrony of complex predicates in Dutch: A case study in grammaticalization. Acta Linguistica Hungarica 50.61-91.

Booij, Geert E. 1990. The boundary between morphology and syntax: separable complex verbs in Dutch. Yearbook of Morphology 1990.54-63.

Dryer, Matthew. 1986. Primary objects, secondary objects and antidative. Language 62.808-845.

Engelenhoven, Aone van. 2006. Verb serialization in Fataluku: The case of 'take'. Paper presented at the Workshop on converbs, medial verbs, and related issues, Leiden 2006.

Fedden, Sebastian, Dunstan Brown, Greville Corbett, Gary Holton, Marian Klamer, Laura C. Robinson and Antoinette Schapper. To appear. Conditions on pronominal marking in the Alor-Pantar languages. Forthcoming. Linguistics.

Haan, John. 2001. The grammar of Adang. PhD thesis, The University of Sydney.

Haspelmath, Martin. 2005. Argument marking in ditransitive alignment types. Linguistic Discovery 3/1.1-21.

Holton, Gary. 2010. Person-marking, verb classes, and the notion of grammatical alignment in Western Pantar (Lamma). Typological and areal analyses: Contributions from East Nusantara, ed. by Michael Ewing and Marian Klamer, 101-121. Canberra: Pacific Linguistics.

Holton, Gary, Marian Klamer, František Kratochvíl, Laura Robinson, and Antoinette Schapper. 2012. The historical relation of the Papuan languages of Alor and Pantar. Oceanic Linguistics 51/1.86-122.

Holton, Gary and Mahalel Lamma Koly.2008. Kamus pengantar Bahasa Pantar Barat. Kupang: Unit Bahasa dan Budaya, GMIT. http://www.uaf.edu/alor/langs/western-pantar/lexicon/

Huber, Juliette. 2005. First steps towards a grammar of Makasae, a language of East Timor. München: Lincom.

-----. 2008. Preliminary remarks on object-marking in Makalero. Linguistics in The Netherlands 2008, ed. by Marjo van Koppen and Bert Botma, 87-96. Amsterdam: Benjamins.

-----. 2011. A grammar of Makalero, a Papuan language of East Timor. PhD thesis, Leiden University.

Klamer, Marian. n.d. Teiwa corpus. Leiden University.

-----. 2008. The semantics of Semantic Alignment in Eastern Indonesia. The Typology of Semantic Alignment, ed. by Mark Donohue and Søren Wichmann, 221- 251.Oxford: Oxford University Press.

-----. 2010a. A grammar of Teiwa. Berlin New York: Mouton De Gruyter. 
-----. 2010b. One item, many faces: 'Come' in Teiwa and Kaera. East Nusantara: Typological and Areal Analyses, ed. by Michael Ewing and Marian Klamer, 203-226. Canberra: Pacific Linguistics.

-----. 2010c. Ditransitive constructions in Teiwa. Studies in ditransitive constructions: A comparative handbook, ed. by Andrej Malchukov, Martin Haspelmath, and Bernard Comrie, 427-455. Berlin New York: Mouton De Gruyter.

Kratochvíl, František. n.d. Abui corpus. Leiden and Singapore.

-----. 2007. A grammar of Abui. PhD dissertation, Leiden University. Utrecht: LOT Publications.

Kratochvíl, František, Sebastian Fedden, Gary Holton, Marian Klamer, Laura C. Robinson, and Antoinette Schapper. 2011. Pronominal systems in Alor-Pantar languages: Development and diachronic stability. Paper given at the 20th International Conference on Historical Linguistics, 28 July Osaka, Japan.

Malchukov, Andrej, Martin Haspelmath and Bernard Comrie. 2010. Ditransitive constructions: A typological overview. Studies in Ditransitive Constructions: A Comparative Handbook, ed. by Andrej Malchukov, Martin Haspelmath, and Bernard Comrie, 1-64. Berlin New York: Mouton De Gruyter.

Malchukov, Andrej. 2010. Analyzing semantic maps: A multifactorial approach. Linguistic Discovery 8/1.176-198.

Schapper, Antoinette. n.d. b. Kamang corpus. Leiden University.

-----. 2010. Bunaq, a Papuan language of central Timor. PhD thesis, Australian National University.

-----. 2011. a. Crossing the border: Historical and linguistic divides among the Bunaq in central Timor. Wacana, Journal of the Humanities of Indonesia 13/1.29-49.

----- 2011. b. Finding Bunaq: The homeland and expansion of the Bunaq in central Timor. Life and land in Timor: Ethnographic papers, ed. by Andrew McWilliam and Elizabeth G. Traube, 163-86. Canberra: ANU E-Press.

Schapper, Antoinette, Juliette Huber and Aone van Engelenhoven. Forthcoming. The historical relations of the Papuan languages of Timor and Kisar. Language and Linguistics in Melanesia.

Siewierska, Anna, and Dik Bakker. 2007. Bound person forms in ditransitive clauses revisited. Functions of Language 14/1.103-125.

Authors' Contact Information:

Marian Klamer

Faculty of Humanities

Leiden University

Box 9515

2300 RA Leiden

The Netherlands

m.a.f.klamer@hum.leidenuniv.nl 
Antoinette Schapper

Faculty of Humanities

Leiden University

Box 9515

2300 RA Leiden

The Netherlands

a_schapper@hotmail.com 